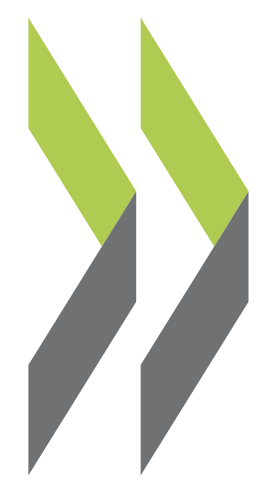

OECD Economics Department Working Papers No. 1304

Links between weak investment and the slowdown

in productivity and potential output growth across the OECD

\section{Patrice Ollivaud, \\ Yvan Guillemette,} David Turner 
Organisation de Coopération et de Développement Économiques

Organisation for Economic Co-operation and Development

06-Jun-2016

ECONOMICS DEPARTMENT

English - Or. English

\section{LINKS BETWEEN WEAK INVESTMENT AND THE SLOWDOWN IN PRODUCTIVITY AND POTENTIAL OUTPUT GROWTH ACROSS THE OECD}

ECONOMICS DEPARTMENT WORKING PAPERS No. 1304

By Patrice Ollivaud, Yvan Guillemette and David Turner

OECD Working Papers should not be reported as representing the official views of the OECD or of its member countries. The opinions expressed and arguments employed are those of the authors.

Authorised for publication by Christian Kastrop, Director, Policy Studies Branch, Economics Department.

Document available in pdfformat only.

All Economics Department Working Papers are available at www.oecd.org/eco/workingpapers

JT03397417

Complete document available on OLIS in its original format

This document and any map included herein are without prejudice to the status of or sovereignty over any territory, to the delimitation of international frontiers and boundaries and to the name of any territory, city or area. 
OECD Working Papers should not be reported as representing the official views of the OECD or of its member countries. The opinions expressed and arguments employed are those of the author(s).

Working Papers describe preliminary results or research in progress by the author(s) and are published to stimulate discussion on a broad range of issues on which the OECD works.

Comments on Working Papers are welcomed, and may be sent to the Economics Department, OECD, 2 rue André-Pascal, 75775 Paris Cedex 16, France.

Comment on the Papers is invited, and may be sent to OECD Economics Department, 2 rue André Pascal, 75775 Paris Cedex 16, France, or by e-mail to eco.contact@oecd.org.

This document and any map included herein are without prejudice to the status of or sovereignty over any territory, to the delimitation of international frontiers and boundaries and to the name of any territory, city or area.

The statistical data for Israel are supplied by and under the responsibility of the relevant Israeli authorities. The use of such data by the OECD is without prejudice to the status of the Golan Heights, East Jerusalem and Israeli settlements in the West Bank under the terms of international law.

\section{(c) OECD (2016)}

You can copy, download or print OECD content for your own use, and you can include excerpts from OECD publications, databases and multimedia products in your own documents, presentations, blogs, websites and teaching materials, provided that suitable acknowledgment of OECD as source and copyright owner is given. All requests for commercial use and translation rights should be submitted to rights@oecd.org 


\section{ABSTRACT/RÉSUMÉ \\ Links between weak investment and the slowdown in productivity and potential output growth across the OECD}

The OECD framework for estimating potential output is combined with previous OECD empirical research to analyse the causes of recent weak productivity growth. Current weak labour productivity growth in many OECD countries reflects historically weak contributions from both total factor productivity (TFP) growth and capital deepening. The slowdown in trend productivity growth in the pre-crisis period is mostly explained by a long-established slowdown in TFP growth, but since the crisis, the further deceleration is mainly due to weak capital deepening, a development apparent in practically every OECD country. Much of the weakness in the growth of the capital stock since the financial crisis can be explained by an accelerator response of investment to continued demand weakness, leading in turn to a deterioration in potential output via a hysteresis-like effect. Circumstantial evidence suggests that a misallocation of capital in the pre-crisis period also contributed to the slowdown in capital stock growth, particularly among the most severely affected countries. In many OECD countries, declining government investment as a share of GDP has further exacerbated post-crisis weakness in capital stock growth, both directly and probably indirectly via adverse spillover effects on business investment. Finally, at a time when the use of conventional macro policy instruments has become increasingly constrained, the slower pace of structural reform represents a missed opportunity, not least because more competitionfriendly product market regulation could have boosted both investment and potential growth.

JEL Classification: E22; E27; E32; E65; E66

Keywords: financial crisis, global financial crisis, potential output, capital stock, investment, capacity, accelerator effect, hysteresis

$* * * * * *$

\section{Les liens entre la faiblesse de l'investissement et le ralentissement de la croissance de la productivité et de la production potentielle dans l'OCDE}

Le cadre général de l'OCDE pour l'estimation du potentiel de production est combiné à des résultats empiriques antérieurs de l'OCDE pour analyser les causes de la faiblesse récente de la croissance de la productivité. La faible croissance de la productivité du travail de ces dernières années reflète des contributions historiquement faibles à la fois de la productivité totale des facteurs (PTF) et de l'intensité capitalistique. Le ralentissement de la croissance tendancielle de la productivité avant la crise est principalement expliqué par un ralentissement de longue date de la croissance de la PTF ; néanmoins, depuis la crise, l'accentuation de la décélération s'explique surtout par une plus faible contribution de l'intensité capitalistique, qui s'observe dans pratiquement tous les pays de l'OCDE. Une part substantielle de la faiblesse de la croissance du stock de capital depuis la crise financière peut s'expliquer par la réponse de l'investissement, via un effet accélérateur, à la faiblesse prolongée de la demande, conduisant à son tour à une détérioration de la production potentielle suivant un effet de type hystérèse. Des preuves circonstancielles suggèrent qu'une mauvaise allocation du capital avant la crise a aussi contribué au ralentissement de la croissance du stock de capital, notamment parmi les pays les plus sévèrement touchés. Dans beaucoup de pays de l'OCDE, la baisse de l'investissement public en point de PIB a encore aggravé la faiblesse post-crise de la croissance du stock de capital, à la fois directement et aussi probablement indirectement via des effets négatifs sur l'investissement des entreprises. Enfin, dans un contexte où les instruments conventionnels de politiques macroéconomiques sont de plus en plus contraints, le ralentissement du rythme des réformes structurelles représente une opportunité manquée, ne serait-ce qu'en raison du soutien à la fois à l'investissement et à la croissance du potentiel qu'auraient pu fournir des réglementations plus adéquates du marché des produits.

Classification JEL : E22 ; E27 ; E32 ; E65 ; E66

Mots clés : crise financière, crise financière globale, potentiel de production, stock de capital, investissement, capacité; effet accélérateur, hystérèse. 


\section{TABLE OF CONTENTS}

\section{LINKS BETWEEN WEAK INVESTMENT AND THE SLOWDOWN IN PRODUCTIVITY AND

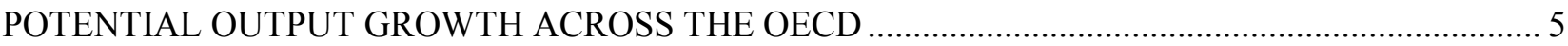

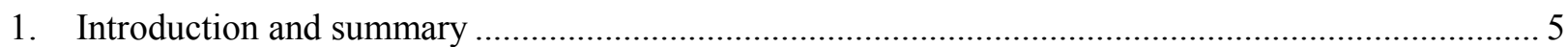

2. The slowdown in aggregate OECD trend labour productivity growth ............................................ 6

3. Country detail of the slowdown in trend labour productivity growth .......................................... 7

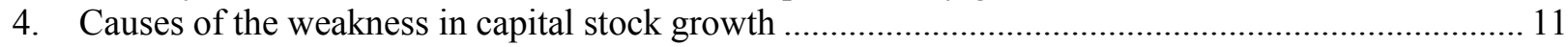

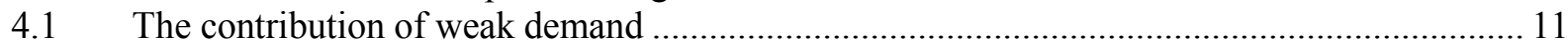

4.2 The contribution from the pre-crisis misallocation of capital................................................. 14

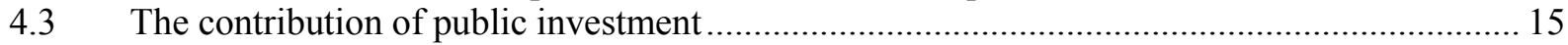

4.4 The contribution from product market regulation reforms .................................................... 16

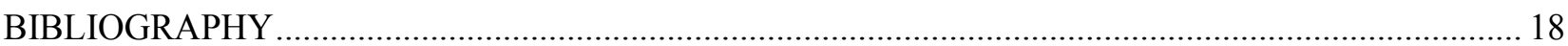

APPENDIX 1. COUNTRY-SPECIFIC DECOMPOSITIONS OF POTENTIAL GROWTH.................... 19

\section{Tables}

Table 1. Trend productivity growth before and after the crisis 10

\section{Figures}

Figure 1. Decomposition of the OECD-wide trend labour productivity growth rate................................ 7

Figure 2. Change in contribution of capital per worker to trend productivity growth ............................. 9

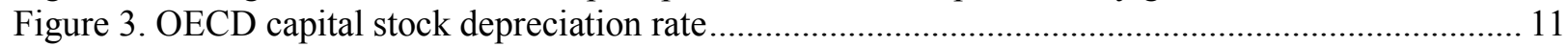

Figure 4. The slowdown in capital growth and the shock to demand ................................................... 12

Figure 5. The slowdown in capital growth and pre-crisis real interest rates .......................................... 14

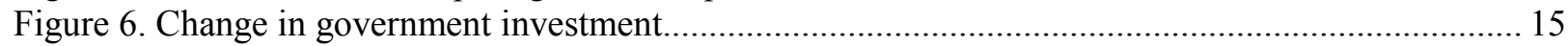

Figure 7. The slowdown in capital stock growth and the post-crisis change in government investment . 16

Figure 8. Improvement in product market regulation across OECD countries ........................................ 17

Figure A1.1. Decomposition of growth of potential output per capita ................................................. 20

\section{Boxes}

Box 1. Simulating the interaction between investment and potential output..... 13 
ECO/WKP(2016)28

\title{
LINKS BETWEEN WEAK INVESTMENT AND THE SLOWDOWN IN PRODUCTIVITY AND POTENTIAL OUTPUT GROWTH ACROSS THE OECD
}

\author{
Patrice Ollivaud, Yvan Guillemette and David Turner ${ }^{1}$
}

\section{Introduction and summary}

1. Following the global financial crisis there has been a marked slowdown in productivity and potential growth across most OECD countries while investment has been unusually weak (OECD, 2016a; OECD, 2015a). This paper considers the links between these phenomena; both the contribution that weak investment has made to lower productivity and potential growth, as well as the extent to which weak investment has been propagated by the shock associated with the financial crisis.

2. The main findings of the paper are as follows:

- Recent weak trend labour productivity growth in many OECD countries reflects historically weak contributions from both total factor productivity (TFP) and capital per worker.

- For most OECD countries, the slowdown in trend productivity growth over the period 2000 to 2007 is mostly explained by a slowdown in TFP growth, but since the crisis, the further deceleration in trend productivity is mostly due to weak growth in capital per worker.

- Much of the recent weakness in the growth of the capital stock can be explained by an accelerator response of investment to the negative demand shock following the financial crisis. Those countries experiencing the most severe downturns have also suffered the most marked slowdown in capital stock growth. This suggests the operation of an important hysteresis-like effect over the post-crisis period, whereby continued weakness in demand has led to a deterioration in potential output via weaker growth in the capital stock.

- Circumstantial evidence suggests that countries which saw greater misallocation of capital in the pre-crisis period, mostly in Southern Europe, also saw a more abrupt post-crisis adjustment in capital stock growth.

- To the extent that macro policy responses, especially from monetary policy, have cushioned the post-crisis downturn, they may have helped to limit the damage to potential growth, although empirical evidence of the beneficial effects of lower interest rates on investment is surprisingly meagre. On the other hand, government investment as a share of GDP since the crisis has fallen

1. The authors are economists and Head of Division, respectively, in the OECD Economics Department. They would like to thank Catherine L. Mann, Jean-Luc Schneider, Peter Hoeller, Balàzs Égert, Nadim Ahmad and Asa Johansson for comments on an earlier version of the paper, as well as Sylvie Toly and Alexandre Kopoin for statistical support and Veronica Humi for technical assistance. 
in many OECD countries and in aggregate across the OECD. This may not only have contributed to a direct reduction in the growth rate of the productive capital stock, but may also have had adverse indirect spillover effects on business investment: countries where government investment has been cut back most sharply are also those where growth of the whole-economy capital stock has slowed the most.

- Recent OECD empirical work suggests that structural reforms which promote competition in product markets tend to boost capital intensity. However, while product marker regulation has become more competition-friendly the rate of improvement has declined in the post-crisis period. Thus, at a time when the use of conventional macro policy instruments has become increasingly constrained, the slower pace of structural reform represents a missed opportunity, not least because of the beneficial effects it would likely have on investment and potential growth.

3. The analysis in the paper is based on estimates of potential output, trend productivity and its components rather than actual output and productivity to try to abstract from cyclical effects which are obviously severe following the crisis, although the uncertainties surrounding trend estimates add an important caveat to any conclusions reached. ${ }^{2}$ The next section analyses the slowdown in trend labour productivity at the aggregate OECD level, whereas section 3 applies the same analysis across individual countries to look for common patterns. A main finding is that weak growth in the capital stock has been the major explanation of post-crisis weakness in productivity growth, so section 4 considers alternative explanations for the weakness in investment. An appendix provides a decomposition of potential growth for individual OECD countries.

\section{The slowdown in aggregate OECD trend labour productivity growth}

4. The current OECD method of estimating potential output assumes a Cobb-Douglas production function, ${ }^{3}$ which can be simplified so that potential output $\left(\mathrm{Y}^{*}\right)$ is expressed in terms of potential employment $\left(\mathrm{N}^{*}\right)$, the capital stock $(\mathrm{K})$ and labour-augmenting trend technical progress $\left(\mathrm{E}^{*}\right)$, so that in logarithmic form:

$$
y^{*}=\alpha\left(n^{*}+e^{*}\right)+(1-\alpha) k
$$

where lower case letters denote logs and $\alpha$ is the wage share. Total factor productivity growth (TFP) is a simple transformation of labour efficiency: $\operatorname{tfp}=\alpha \mathrm{e}^{*}$.

5. The definition of potential output used here is the non-housing whole-economy capital stock in line with the current OECD methodology for estimating potential output. ${ }^{4,5}$ A rationale for using the actual capital stock, rather than a trend measure, is that it represents installed capacity which in principle could be utilised without generating inflationary pressure. A more practical reason for using the actual capital stock

2. See Box 1.5 of OECD (2015b) and Turner et al. (2016) for a discussion of revisions to OECD measures of potential output.

3. For further details see Appendix 3 of Turner et al. (2016).

4. The capital stock data for 20 OECD countries, including all G7 countries, is taken from the OECD Statistics Directorate, but for other countries (Greece, Chile, Colombia, Czech Republic, Hungary Iceland, Israel, Latvia Mexico, Norway, Poland, Sweden, Slovak Republic, Slovenia and Turkey) it is generated from investment data using a perpetual inventory method.

5. The measure of capital is also a measure of capital stock which is more appropriate for measuring potential output rather than a measure of capital services, which is more cyclical and better captures the contribution of capital to actual output. 
is the difficulty of identifying its trend component, particularly in the aftermath of the financial crisis. The sensitivity of the analysis to this choice is discussed further below.

6. An expression for trend labour productivity growth can then be derived in terms of a contribution from labour efficiency (or equivalently a contribution from TFP) and a contribution from changes in capital per worker, by substracting potential employment from both sides of [1]:

$$
\Delta\left(\mathrm{y}^{*}-\mathrm{n}^{*}\right)=\alpha \Delta \mathrm{e}^{*}+(1-\alpha) \Delta\left(\mathrm{k}-\mathrm{n}^{*}\right) .
$$

7. Aggregate OECD trend labour productivity declined from over $13 / 4$ per cent per annum in 2000 to around $1 \%$ per annum just prior to the crisis (Figure 1). In the immediate aftermath of the crisis trend labour productivity slumped further, but has since recovered to about $3 / 4$ per cent per annum. The widespread slowdown in productivity growth is the most important reason of the slowdown in the growth rate of GDP per capita (a proxy for living standards), although other factors, such as ageing populations, have also contributed (see Box 1.3 of OECD, 2015c and Appendix 1).

8. The decline in trend labour productivity growth can be split into contributions from total factor productivity (TFP) and capital per worker on the basis of the decomposition described in [2] (Figure 1). The slowdown in trend labour productivity growth in the pre-crisis period is mostly explained by a longestablished slowdown in trend TFP growth. OECD trend TFP growth gradually slowed from 2000 to 2007 , and dipped further following the crisis, but has since recovered to about pre-crisis (2007) growth rates. Conversely, the contribution from capital deepening slowed during the crisis and has remained subdued due to the prolonged weakness in investment. The slowdown in the contribution from growth in capital deepening of 0.4 percentage point per annum entirely explains the slowdown in trend productivity growth between 2007 and 2015.

Figure 1. Decomposition of the OECD-wide trend labour productivity growth rate

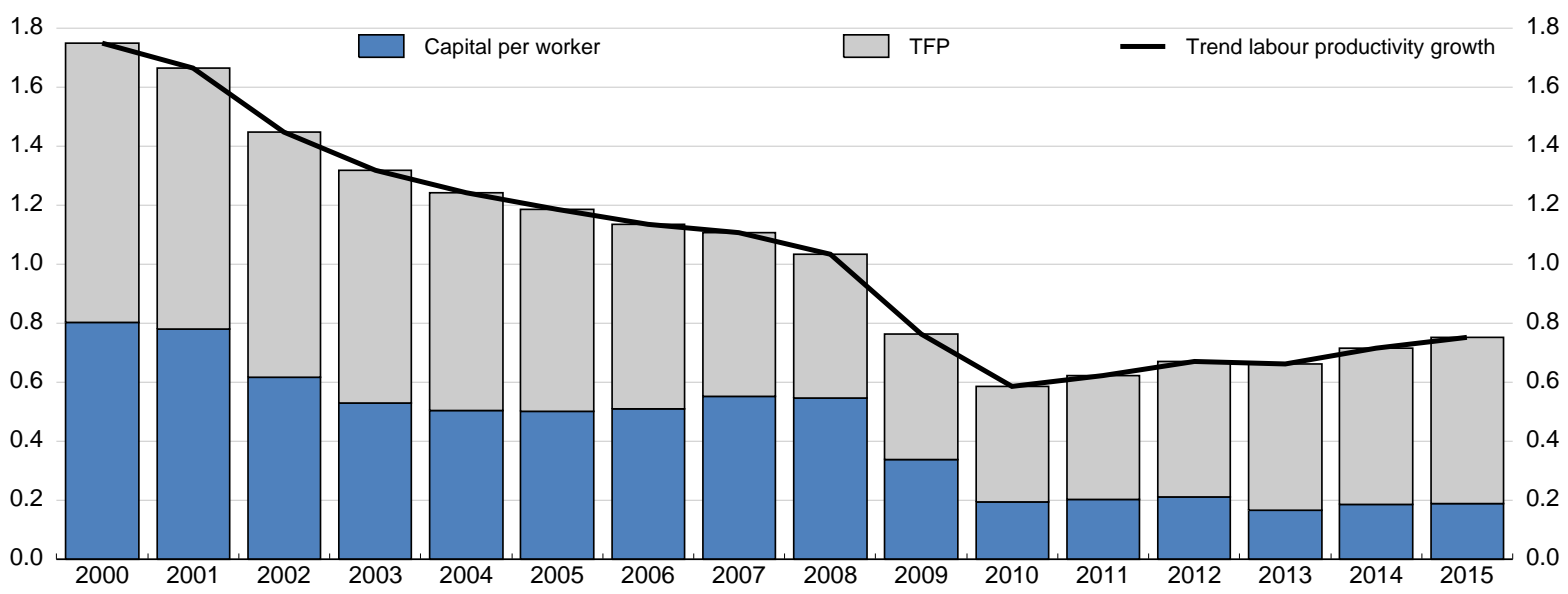

Note: The basis for the decomposition is summarised by equation [2] in the text.

Source: OECD Economic Outlook 99 database.

\section{Country detail of the slowdown in trend labour productivity growth}

9. The pattern of the decline in trend productivity and the contributions from TFP and capital per worker which are apparent for the aggregate OECD are also present, to differing degrees, in the overwhelming majority of OECD countries. Trend labour productivity growth slowed in most OECD 
countries between 2000 and the start of the crisis, and it has slowed further since the crisis (see Table 1 and Figure A1.1 in Appendix 1 for individual country details). Looking across all OECD countries, a striking pattern is that slowing trend labour productivity growth over the period 2000 to 2007 was mainly due to slowing TFP growth, but since the crisis the further slowdown is mostly explained by weaker growth in capital per worker (Figure 2, panels A and B):

- Between 2000 and 2007, trend labour productivity growth slowed in all but four of the 34 OECD countries. For three-quarters of OECD countries, weakening TFP growth accounts for most of this slowdown rather than capital deepening. In virtually all OECD countries, TFP growth slowed over this period and, for more than half of them, the contribution from TFP declined by more than $1 / 2$ percentage point per annum (see Figure 2, panel B and the highlighted cells in column C4 of Table 1). Conversely, the contribution from capital per worker increased between 2000 and 2007 in as many countries as it declined (see Figure 2, panel A and column B4 of Table 1).

- Between 2007 and 2015, trend labour productivity decelerated further in three quarters of OECD countries, with a weakening contribution from capital deepening, rather than TFP, accounting for the bulk of this deceleration. Between 2007 and 2015, the contribution from capital deepening decreased in practically all OECD countries (Figure 2, panel A), whereas that from TFP improved in about half of all OECD countries (Figure 2, panel B). In around one-third of all OECD countries, the contribution from capital deepening declined by more than $1 / 2$ percentage point per annum (see highlighted cells in column B5 of Table 1), whereas the contribution from TFP declined by a similar magnitude in only three countries (column C5 of Table 1).

10. Despite similar patterns across many OECD countries, some have been more severely affected than others:

- The slowdown in capital per worker was greatest among those countries most severely affected by the crisis. In Estonia, Greece, Iceland, Portugal, Slovenia and Turkey, slowing growth in capital per worker dragged down post-crisis trend productivity growth by more than 1 percentage point per annum between 2007 and 2015.

- Slower TFP growth contributed more than 1 percentage point per annum to slowing trend labour productivity growth between 2000 and 2015 in the Czech Republic, Finland, Greece, Hungary, Ireland, Poland, the Slovak Republic and Sweden.

11. Recent contributions of both TFP and capital per worker to trend labour productivity growth appear historically weak in many OECD countries:

- While TFP growth has recovered since 2007 in many countries, recent performance remains weak: its contribution to trend labour productivity growth is estimated to be less than $1 / 2$ percentage point in 2015 in two-thirds of OECD countries (in 2000 the corresponding share was only one-fifth). The TFP contribution was more than 1 percentage point in only four countries (whereas in 2000 this was the case for nearly half of all OECD countries) and no major country is among them. The euro area stands out with a TFP growth contribution of only 0.2 percentage points in 2015.

- The recent contribution of capital deepening to trend productivity growth has not only declined, but remains weak in many countries: in 2015 it is estimated to be less than one quarter percentage point in one-third of OECD countries (compared to two countries with such a low contribution in 2000 and 2007); and more than 1 percentage point in only four countries (compared to 35 and $45 \%$ of countries in 2000 and 2007, respectively). 
Figure 2. Explaining the change in trend labour productivity growth, 2000-07 and 2007-15

A. Contribution from capital deepening (\% points per annum)

Frequency distribution of countries

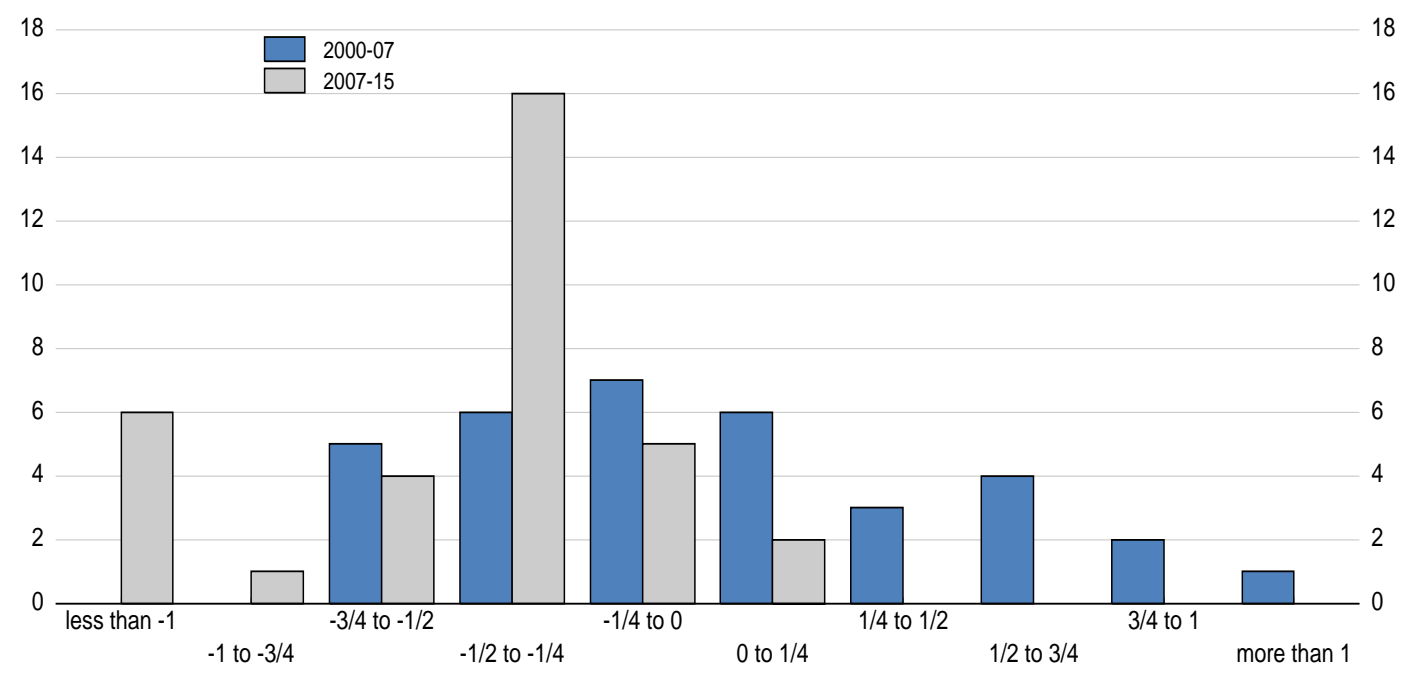

B. Contribution from TFP growth (\% points per annum)

Frequency distribution of countries

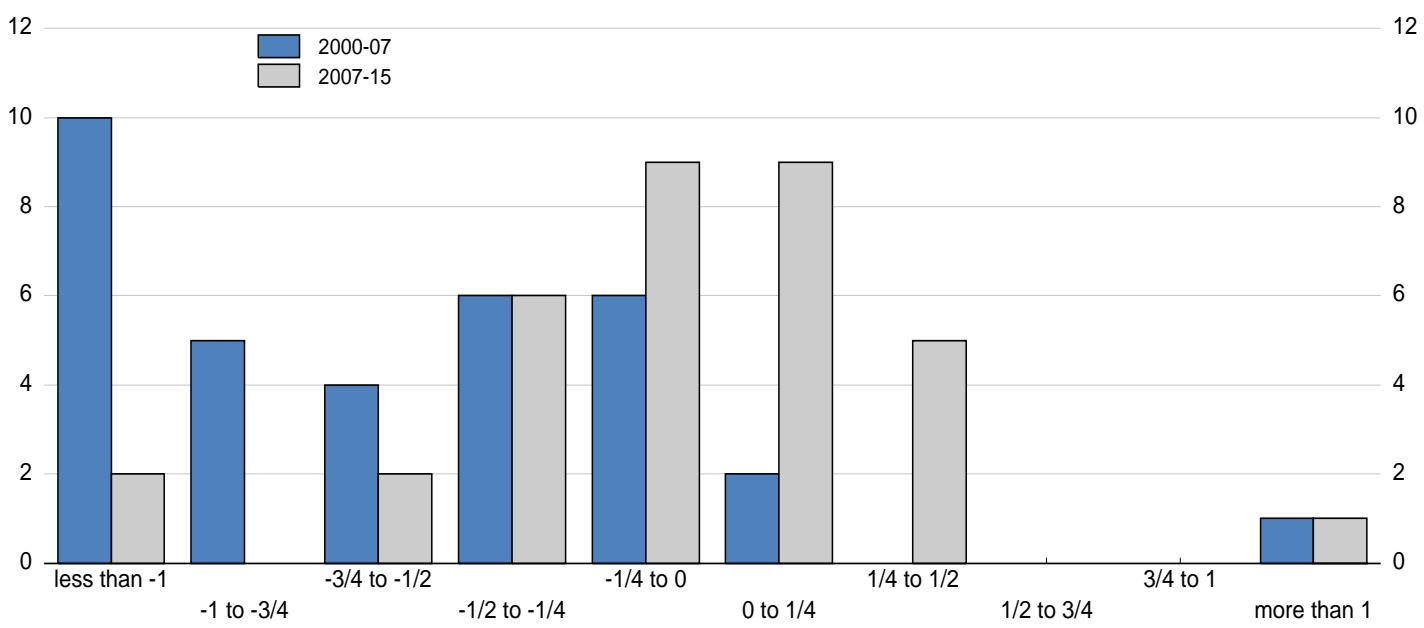

Note: The vertical axis denotes the number of OECD countries and the horizontal axis measures the percentage point per annum contribution to the change in trend productivity growth from either capital per worker (panel A) or TFP (panel B).

Source: OECD Economic Outlook 99 database. 
Table 1. Trend productivity growth before and after the crisis

\begin{tabular}{|c|c|c|c|c|c|c|c|c|c|c|c|c|c|c|c|}
\hline & \multicolumn{5}{|c|}{ (a) Trend productivity growth (\% p.a.) } & \multicolumn{5}{|c|}{ (b) Capital per worker contribution (\% p.a.) } & \multicolumn{5}{|c|}{ (c) TFP contribution (\% p.a.) } \\
\hline & $(1 \mathrm{~A})$ & $(2 \mathrm{~A})$ & $(3 \mathrm{~A})$ & $\begin{array}{c}(4 A)= \\
(2 A)-(1 A)\end{array}$ & $\begin{array}{c}(5 A)= \\
(3 A)-(2 A)\end{array}$ & (1B) & $(2 \mathrm{~B})$ & (3B) & $\begin{array}{c}(4 \mathrm{~B})= \\
(2 \mathrm{~B})-(1 \mathrm{~B})\end{array}$ & $\begin{array}{c}(5 \mathrm{~B})= \\
(3 \mathrm{~B})-(2 \mathrm{~B})\end{array}$ & (1C) & (2C) & (3C) & $\begin{array}{c}(4 \mathrm{C})= \\
(2 \mathrm{C})-(1 \mathrm{C})\end{array}$ & $\begin{array}{c}(5 C)= \\
(3 C)-(2 C)\end{array}$ \\
\hline & 2000 & 2007 & 2015 & $\begin{array}{c}\text { Change } \\
2007-2000\end{array}$ & $\begin{array}{c}\text { Change } \\
2015-2007\end{array}$ & 2000 & 2007 & 2015 & $\begin{array}{c}\text { Change } \\
2007-2000\end{array}$ & $\begin{array}{c}\text { Change } \\
2015-2007\end{array}$ & 2000 & 2007 & 2015 & $\begin{array}{c}\text { Change } \\
2007-2000\end{array}$ & $\begin{array}{c}\text { Change } \\
2015-2007\end{array}$ \\
\hline Australia & 1.6 & 1.0 & 1.3 & -0.6 & 0.3 & 0.2 & 0.8 & 0.7 & 0.6 & -0.2 & 1.4 & 0.2 & 0.6 & -1.2 & 0.5 \\
\hline Austria & 1.6 & 0.8 & 0.1 & -0.9 & -0.6 & 0.7 & 0.4 & 0.1 & -0.4 & -0.3 & 0.9 & 0.4 & 0.1 & -0.5 & -0.3 \\
\hline Belgium & 1.5 & 0.7 & 0.7 & -0.8 & 0.0 & 0.6 & 0.3 & 0.3 & -0.3 & 0.0 & 0.9 & 0.4 & 0.4 & -0.5 & 0.0 \\
\hline Canada & 1.3 & 0.8 & 0.9 & -0.5 & 0.1 & 0.3 & 0.5 & 0.4 & 0.2 & -0.1 & 1.0 & 0.3 & 0.5 & -0.7 & 0.3 \\
\hline Switzerland & 1.4 & 0.9 & 0.2 & -0.6 & -0.6 & 0.9 & 0.3 & 0.0 & -0.5 & -0.3 & 0.6 & 0.5 & 0.2 & 0.0 & -0.3 \\
\hline Chile & 2.5 & 1.5 & 1.1 & -1.0 & -0.4 & 1.9 & 1.8 & 1.4 & 0.0 & -0.4 & 0.7 & -0.3 & -0.3 & -0.9 & 0.0 \\
\hline Germany & 1.1 & 0.6 & 0.2 & -0.5 & -0.4 & 0.4 & 0.1 & -0.2 & -0.3 & -0.3 & 0.7 & 0.5 & 0.5 & -0.2 & -0.1 \\
\hline Denmark & 1.7 & 0.6 & 0.5 & -1.1 & -0.1 & 0.8 & 0.6 & 0.1 & -0.2 & -0.5 & 0.9 & 0.0 & 0.4 & -0.9 & 0.4 \\
\hline Spain & 0.6 & 0.9 & 0.7 & 0.4 & -0.2 & 0.7 & 1.1 & 0.7 & 0.5 & -0.5 & -0.1 & -0.2 & 0.0 & -0.1 & 0.2 \\
\hline Estonia & & 4.0 & 1.8 &.. & -2.2 & 2.3 & 3.4 & 1.2 & 1.2 & -2.3 & & 0.6 & 0.6 & & 0.0 \\
\hline Finland & 2.4 & 0.9 & 0.0 & -1.5 & -0.8 & 0.2 & 0.4 & 0.0 & 0.1 & -0.4 & 2.1 & 0.5 & 0.1 & -1.6 & -0.5 \\
\hline France & 1.1 & 0.8 & 0.5 & -0.3 & -0.4 & 0.4 & 0.5 & 0.1 & 0.1 & -0.4 & 0.7 & 0.3 & 0.3 & -0.4 & 0.0 \\
\hline United Kingdom & 2.1 & 0.9 & 0.9 & -1.1 & 0.0 & 1.0 & 0.9 & 0.5 & 0.0 & -0.4 & 1.1 & 0.0 & 0.4 & -1.1 & 0.4 \\
\hline Greece & 2.7 & 0.5 & -1.2 & -2.2 & -1.7 & 0.6 & 1.0 & -0.2 & 0.4 & -1.2 & 2.1 & -0.5 & -1.0 & -2.6 & -0.5 \\
\hline Hungary & 3.6 & 2.2 & 1.2 & -1.4 & -1.0 & 1.4 & 1.5 & 0.8 & 0.2 & -0.7 & 2.2 & 0.7 & 0.4 & -1.5 & -0.2 \\
\hline Ireland & 3.2 & 2.6 & 2.5 & -0.5 & -0.2 & 1.1 & 1.6 & 1.6 & 0.6 & -0.1 & 2.1 & 1.0 & 0.9 & -1.1 & -0.1 \\
\hline Iceland & 2.6 & 2.8 & 1.0 & 0.2 & -1.8 & 1.4 & 1.9 & 0.4 & 0.5 & -1.5 & 1.2 & 0.9 & 0.6 & -0.3 & -0.3 \\
\hline Israel & 1.5 & 0.8 & 0.6 & -0.7 & -0.2 & 1.2 & 0.4 & 0.3 & -0.7 & -0.1 & 0.3 & 0.4 & 0.3 & 0.0 & -0.1 \\
\hline Korea & 3.9 & 2.8 & 1.9 & -1.0 & -0.9 & 1.9 & 1.3 & 0.7 & -0.6 & -0.5 & 2.0 & 1.6 & 1.2 & -0.4 & -0.4 \\
\hline Luxembourg & 0.9 & 0.0 & 0.2 & -0.9 & 0.2 & 0.3 & -0.2 & -0.2 & -0.4 & 0.0 & 0.6 & 0.2 & 0.4 & -0.4 & 0.2 \\
\hline Mexico & 1.2 & 0.2 & 1.2 & -1.0 & 1.0 & 1.2 & 1.0 & 0.8 & -0.2 & -0.2 & -0.1 & -0.8 & 0.4 & -0.8 & 1.2 \\
\hline Netherlands & 1.6 & 0.8 & 0.6 & -0.9 & -0.1 & 0.9 & 0.6 & 0.3 & -0.2 & -0.3 & 0.8 & 0.2 & 0.4 & -0.6 & 0.2 \\
\hline Norway & 2.1 & 1.8 & 0.6 & -0.3 & -1.2 & 0.7 & 1.1 & 0.4 & 0.4 & -0.7 & 1.5 & 0.7 & 0.2 & -0.8 & -0.5 \\
\hline New Zealand & 1.2 & 0.9 & 0.6 & -0.3 & -0.3 & 0.2 & 0.7 & 0.3 & 0.6 & -0.4 & 1.0 & 0.1 & 0.3 & -0.9 & 0.1 \\
\hline Poland & 5.2 & 3.0 & 2.5 & -2.3 & -0.5 & 2.0 & 1.3 & 1.0 & -0.7 & -0.3 & 3.3 & 1.7 & 1.5 & -1.6 & -0.2 \\
\hline Portugal & 2.1 & 1.3 & 0.4 & -0.8 & -0.8 & 2.0 & 1.4 & 0.3 & -0.6 & -1.1 & 0.1 & -0.1 & 0.2 & -0.2 & 0.3 \\
\hline Slovak Republic & 3.8 & 4.6 & 1.8 & 0.8 & -2.7 & 0.8 & 1.6 & 0.7 & 0.8 & -0.8 & 3.0 & 3.0 & 1.1 & 0.0 & -1.9 \\
\hline Slovenia & 3.0 & 2.1 & 1.2 & -1.0 & -0.8 & 1.3 & 1.4 & 0.4 & 0.1 & -1.0 & 1.7 & 0.7 & 0.8 & -1.1 & 0.2 \\
\hline Sweden & 2.8 & 1.5 & 0.9 & -1.3 & -0.6 & 0.8 & 0.5 & 0.2 & -0.3 & -0.3 & 1.9 & 0.9 & 0.7 & -1.0 & -0.2 \\
\hline Turkey & 2.3 & 2.8 & 1.0 & 0.4 & -1.8 & 1.3 & 2.1 & 0.5 & 0.8 & -1.5 & 1.1 & 0.7 & 0.5 & -0.4 & -0.2 \\
\hline United States & 2.0 & 1.5 & 1.0 & -0.5 & -0.5 & 0.8 & 0.6 & 0.3 & -0.2 & -0.3 & 1.1 & 0.9 & 0.7 & -0.2 & -0.2 \\
\hline Euro area & 1.2 & 0.7 & 0.3 & -0.5 & -0.4 & 0.5 & 0.5 & 0.1 & 0.0 & -0.4 & 0.6 & 0.2 & 0.2 & -0.4 & 0.0 \\
\hline OECD total & 1.7 & 1.1 & 0.8 & -0.6 & -0.4 & 0.8 & 0.6 & 0.2 & -0.3 & -0.4 & 0.9 & 0.6 & 0.6 & -0.4 & 0.0 \\
\hline OECD median & 2.0 & 0.9 & 0.8 & -1.1 & -0.1 & 0.8 & 0.9 & 0.3 & 0.0 & -0.5 & 1.0 & 0.4 & 0.4 & -0.6 & 0.0 \\
\hline
\end{tabular}

Source: OECD Economic Outlook 99 database. 


\section{Causes of the weakness in capital stock growth}

12. The slowdown in the contribution of capital to productivity growth is, in an accounting sense, due both to a declining investment rate and to a trend rise in scrapping rates (Figure 3). ${ }^{6}$ The trend rise in scrapping rates reflects a change in the asset composition of capital towards assets which have shorter lives, such as ICT-related assets. However, given that the trend rise in the scrapping rate clearly pre-dates the financial crisis and shows no sign of accelerating following the crisis, the current section focuses on explanations for the post-crisis weakness in investment.

\section{Figure 3. OECD capital stock depreciation rate}

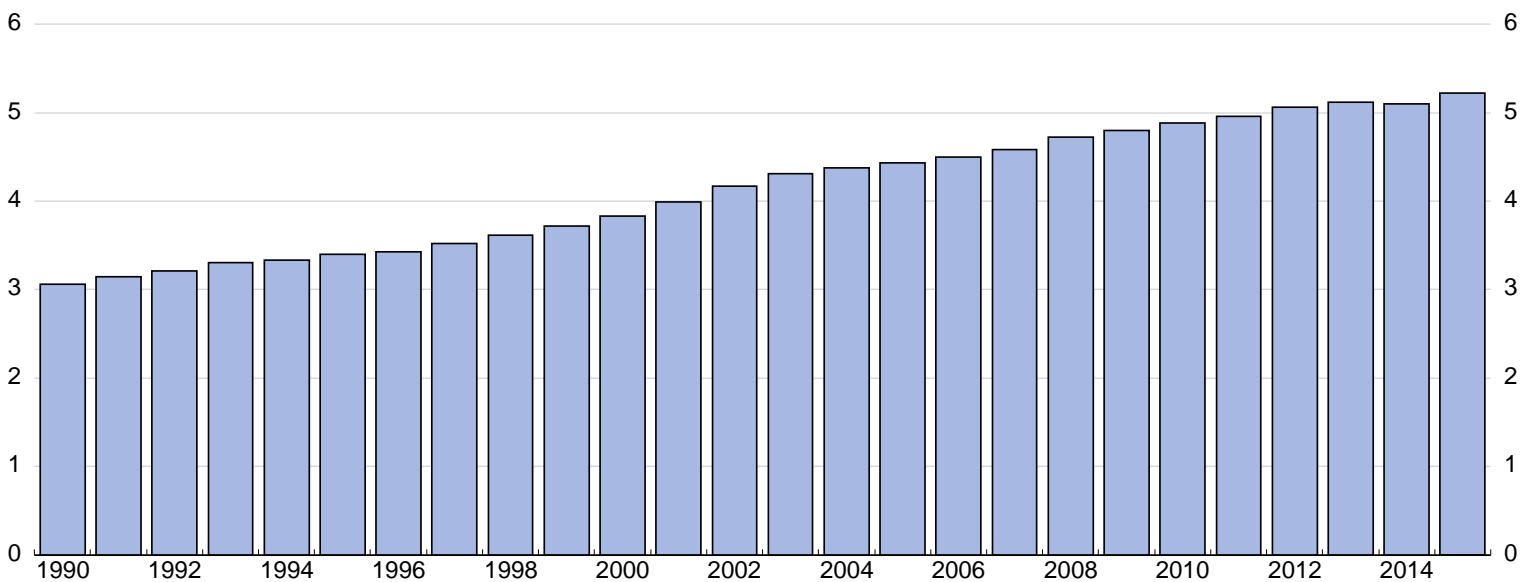

Source: OECD Economic Outlook 99 database.

\subsection{The contribution of weak demand}

13. The collapse in demand precipitated by the financial crisis, as well as its persistent weakness and uncertain outlook since then, is perhaps the most obvious reason why investment has been so weak given that empirically estimated investment equations are usually dominated by 'accelerator' effects operating through demand. A recent chapter on investment in the OECD Economic Outlook reported "New OECD empirical analysis based on a model linking investment with GDP confirms the importance of output developments in explaining movements in business investment... the model largely tracks the downturn in investment at the height of the crisis and the dynamics in recent years. So it remains the case that the predominant factor associated with sluggish investment since the crisis is persistently weak output developments" OECD (2015b). This implies that severe and prolonged weakness in demand can lead to a sustained period of weak investment, which in turn weakens productivity and potential output via its supply-side effect on the capital stock.

14. To illustrate the possible magnitude of this hysteresis-like effect, a simple model is constructed by combining a recently estimated pooled investment equation for OECD countries with equations for potential output and the output gap, and applying shocks to the model that mimic the effect of the financial crisis on output gaps (Box 1). The results suggest that the demand shock associated with the financial crisis

6. The scrapping rate here corresponds to national accounts related measures of depreciation which weight together scrapping rates on different asset types. It does not attempt to quantify capital that became economically redundant as a consequence of the financial crisis and in that sense may under-estimate the decline in capital accumulation following the crisis. 
may have reduced the aggregate OECD capital stock by about 31/4 per cent and the level of potential output in the OECD by more than $1 \%$ by 2015 . The implied reduction in the average growth rate of the capital stock explains about half of the reduced contribution from capital deepening to trend productivity growth observed since the crisis. Formally, the model described in Box 1 implies there will be no permanent longrun damage to potential output, but, as demonstrated in the simulation, the adverse effect of a prolonged slump can reduce potential output growth over decades, thus giving the impression of hysteresis-like weakness in both capital accumulation and productivity. ${ }^{7}$ Using a more elaborate model calibrated on the United States, Hall (2016) also concludes that depletion of the capital stock is the most important of the mechanisms propagating the shock represented by the financial crisis of 2008.

15. The calibrated simulation in Box 1 is intended to reflect changes in aggregate OECD output. However, for many OECD countries, the shock to demand, here proxied by the output gap, was much more severe than in the OECD as a whole. Cross-country evidence suggests that countries which experienced the largest cumulative output gap following the crisis also experienced the most pronounced slowdown in capital stock growth (Figure 4).

Figure 4. The slowdown in capital growth and the shock to demand

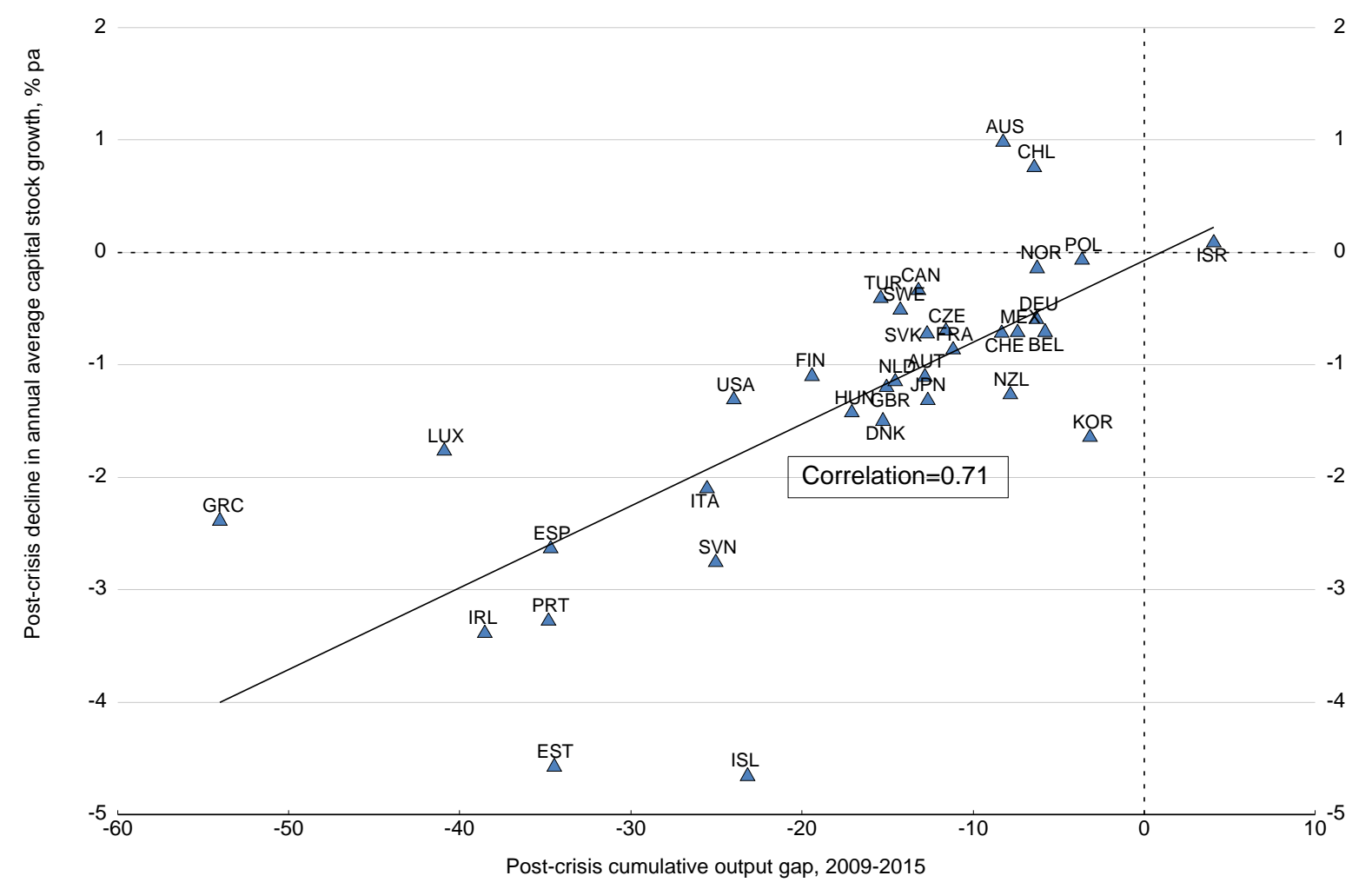

Source: OECD Economic Outlook 99 database.

7. In the very long run, the model described in Box 1 implies that the path of the capital stock will eventually return to the 'no-shock' baseline trajectory. However, the model illustrates that a large negative demand shock will have long-lasting adverse consequences for potential output that lasts decades, hence the description of 'hysteresis-like weakness in capital accumulation and productivity'. 
ECO/WKP(2016)28

\section{Box 1. Simulating the interaction between investment and potential output}

This box sets out a 4-equation calibrated dynamic model to simulate the interaction between investment and potential output for the aggregate OECD.

The quarterly model is based on a standard Cobb-Douglas production function, as described in Section 2 (equation [1]), where $y^{*}$ is potential output, $n$ is the labour input, $e$ is labour efficiency and $k$ is the capital stock (all in logs). The second equation defines the output gap $(G A P)$ as the difference between actual and potential real output. The third equation, inspired by the OECD long-term scenarios model discussed in Johansson et al. (2013), ensures that any output gap closes smoothly over a few years and includes an error term $(\varepsilon)$ to allow the output gap to be calibrated. Finally, the last equation determines the dynamics of the capital stock and is calibrated based on the results from pooled estimation across 15 OECD countries in Appendix 1 of OECD (2015a), with short-term dynamics that include one lag of the change in the capital stock, three lags of the change in actual output and an error-correction term that respects the estimated long-run elasticity of capital to output of 1.23. For simplicity, other variables in the estimated equation are dropped (see Tables 3.A1.2 and 3.A1.3 of OECD, 2015a), except the lagged change in foreign output, whose coefficient is assumed to apply to (and is added to the coefficient on) domestic output. Other variables, for example capturing the effect of financial constraints or uncertainty, while statistically significant, have much less economic importance than output when judged in terms of the effect from a one-standard deviation shock.

$$
\begin{aligned}
& y_{t}^{*}=\frac{2}{3}(n+e)+\frac{1}{3} k_{t} \\
& y_{t}=y_{t}^{*}+G A P_{t} \\
& G A P_{t}=0.96 \cdot G A P_{t-1}-0.07 \cdot G A P_{t-2}+\varepsilon_{t} \\
& \Delta k_{t}=0.95 \cdot \Delta k_{t-1}+0.015 \cdot \Delta y_{t-1}+0.006 \cdot \Delta y_{t-2}+0.004 \cdot \Delta y_{t-3}-0.002 \cdot\left(k_{t-1}-1.23 \cdot y_{t-1}\right)
\end{aligned}
$$

The model is shocked by calibrating the error term so that the output gap follows a path corresponding to the estimated aggregate OECD output gap from the last quarter of 2007 to the end of 2015. Other variables are determined by the model and so is the output gap after 2015. In the simulation, which starts in the last quarter of 2008, the fall in output from end-2007 and the persistent negative output gap drag the capital stock down by $3.3 \%$ below the steady-state value by 2015 and a maximum of $3.7 \%$ by 2018 . Moreover, through its influence on potential output, this fall in the capital stock lowers potential output as much as $1.1 \%$ below its equilibrium value by 2015 , with a trough of $1.2 \%$ in 2018 . Thus, to the extent that the model's calibration is empirically valid, a substantial part of the downward revisions to potential output and trend labour productivity since the crisis can be attributed to weak investment.

The impact of weak investment on the capital stock and potential output Per cent

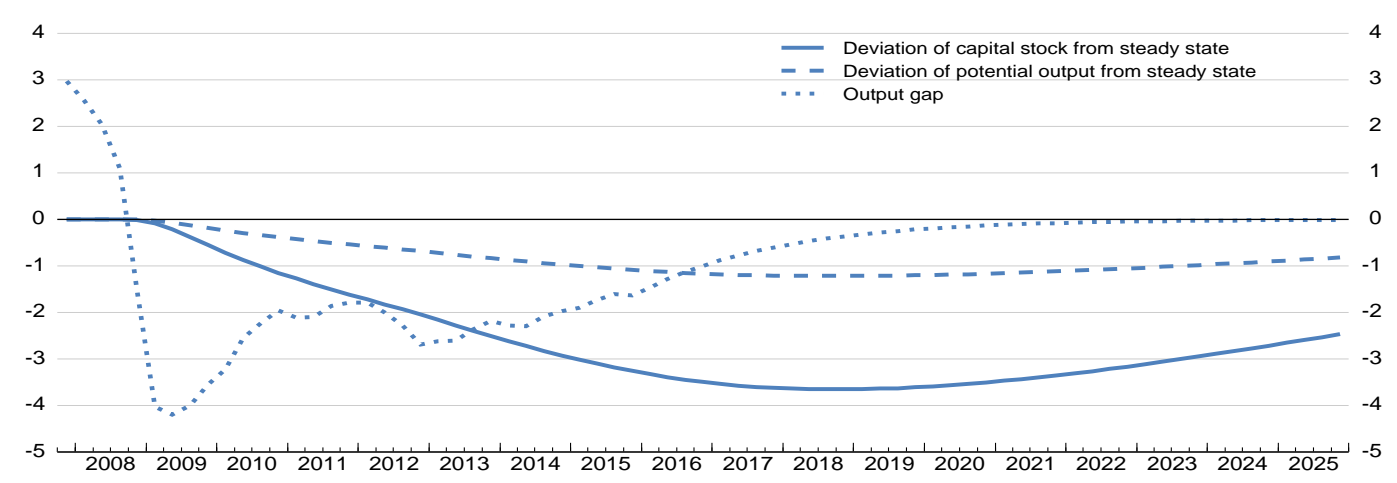

Source: OECD calculations using the OECD Economic Outlook 99 database. 


\subsection{The contribution from the pre-crisis misallocation of capital}

16. A complementary explanation for the weakness of investment in the post-crisis period is that it partly reflects the 'hangover' from the misallocation of resources which occurred in the pre-crisis period during a long period of unusually low interest rates (see also Borio et al., 2015). The misallocation of capital was characterised by housing and construction booms in many countries and in some EU countries may have been facilitated by the inefficient use of EU funds. Those countries which experienced the lowest short-term real interest rates over the pre-crisis period - most notably Estonia, Greece, Ireland, Portugal and Spain - were those which experienced the sharpest slowdown in capital stock growth in the post-crisis period (Figure 5). Distinguishing the extent to which the post-crisis decline in investment is a response to the adverse demand shock or a pre-crisis misallocation would be possible if the analysis explicitly identified the trend capital stock. However, as previously discussed, the current OECD approach to estimating potential output does not do so, particularly because it is so difficult to identify the trend capital stock.

Figure 5. The slowdown in capital growth and pre-crisis real interest rates

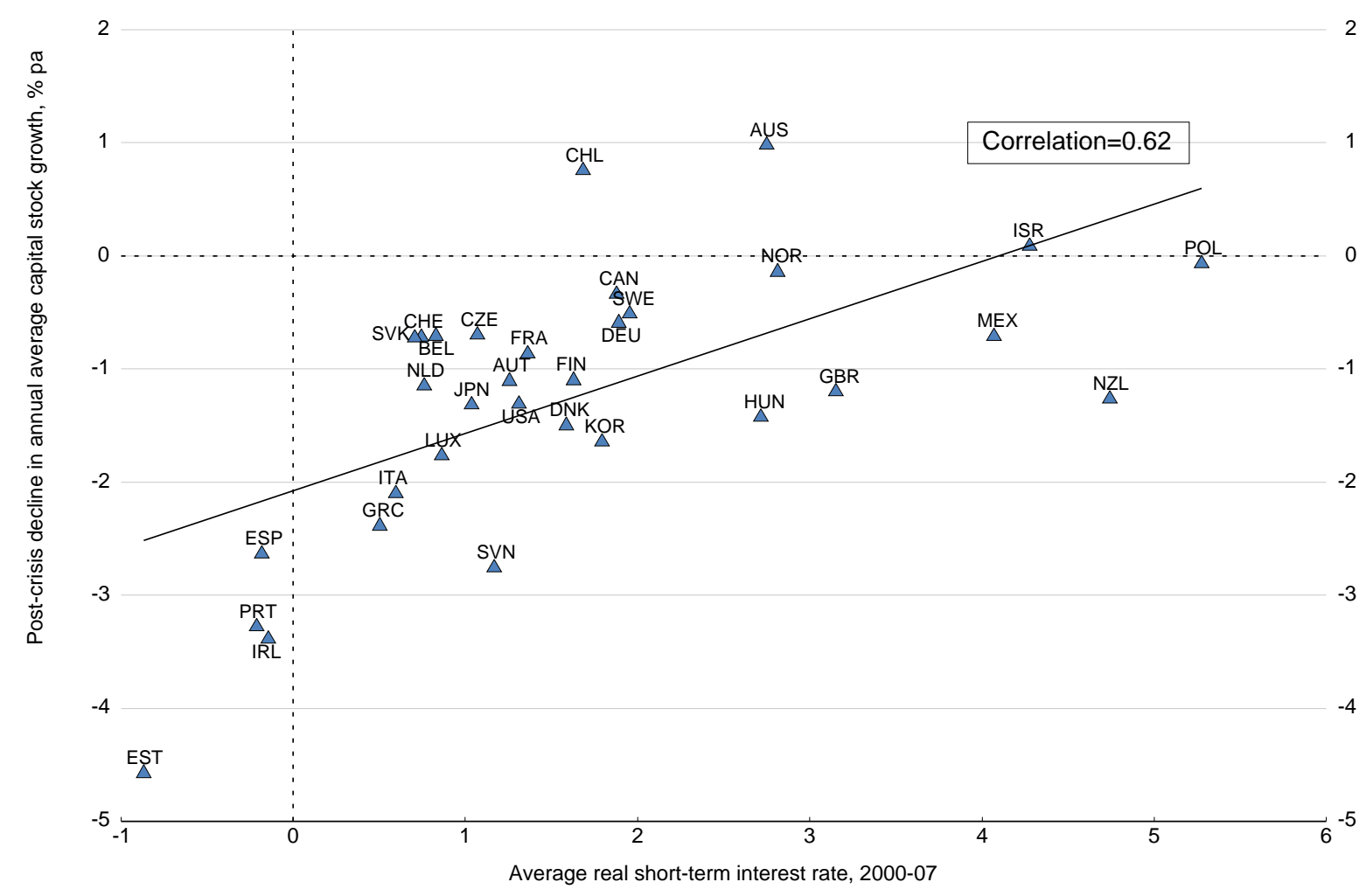

Note: Excludes Iceland and Turkey.

Source: OECD Economic Outlook 99 database. 


\subsection{The contribution of public investment}

17. To the extent that macro policy responses, especially from monetary policy, have cushioned the post-crisis downturn, they may have helped to limit the damage to potential growth, although empirical evidence of the beneficial effects of lower interest rates on investment is surprisingly meagre (OECD, 2015b).

18. The most direct contribution of policy to growth of the whole-economy capital stock comes from government investment, and it has fallen as a share of GDP compared with pre-crisis levels for the OECD as a whole and among nearly half of OECD countries for which data are readily available (Figure 6). Among those countries shown in Figure 6 for which government investment has fallen as a share of GDP relative to a pre-crisis average, the fall in government investment typically accounts for more than one-fifth of the fall of the share of total investment in GDP. Those countries where government investment was cut back most sharply are also those where growth of the whole-economy capital stock declined the most (Figure 7). The correlation between government investment and the change in post-crisis capital stock growth may partly reflect the fact that many of the countries that were most severely affected by the crisis - including Iceland, Greece, Portugal and Spain - were also under the most pressure to undertake fiscal consolidation measures. Indeed, cuts to public fixed investment accounted for about one-fifth of the consolidation effort between 2009 and 2012 in the euro area, the United Kingdom and the United States, and as much as two-fifths in Spain, despite advice to the contrary from the OECD and others (OECD, 2013).

Figure 6. Change in government investment

2015 relative to average over $2000-07$, percentage of GDP

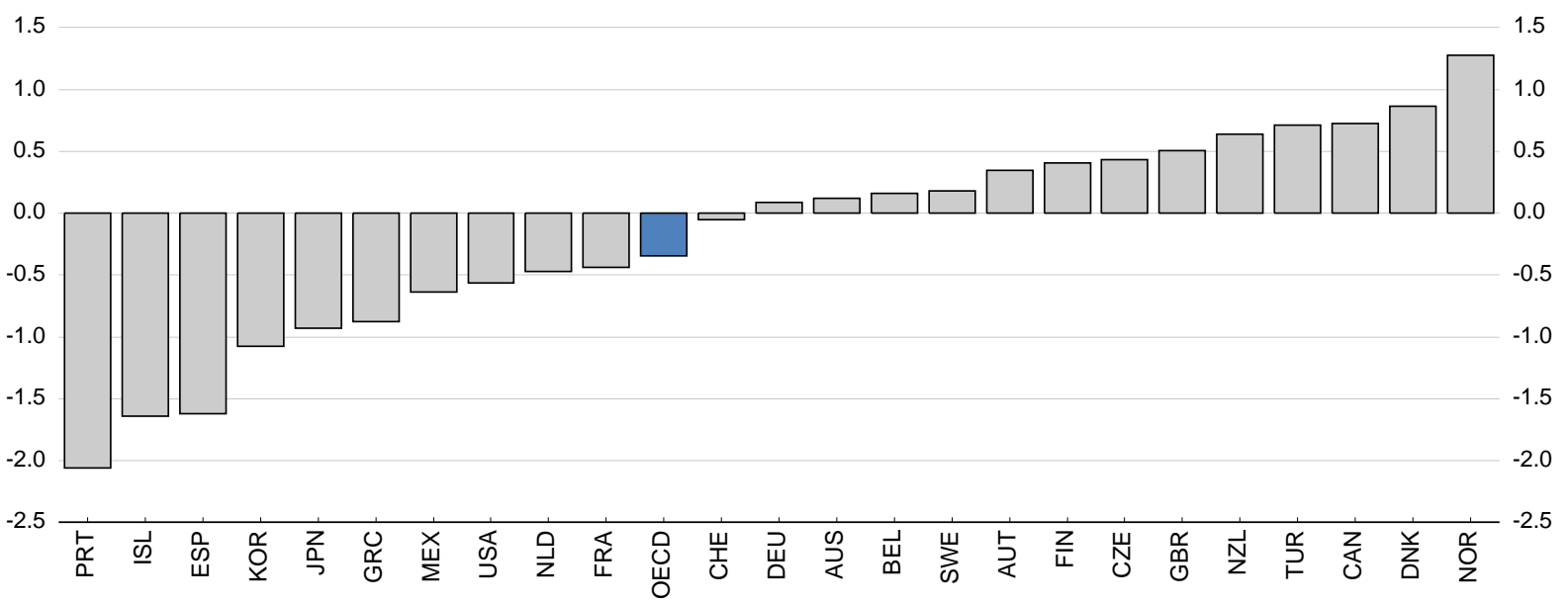

Source: OECD Economic Outlook 99 database.

19. Falling government investment may not only have contributed to a direct reduction in the growth rate of the productive capital stock, but may also have had adverse indirect spillover effects on business investment and productivity. A recent meta-analysis by Bom and Lighart (2014) suggests that the effect of public investment on private sector investment and activity is positive, being larger for: public capital installed by local/regional governments; core public capital (roads, railways, utilities, etc.); and at longer horizons. There is also much existing literature to suggest that public investment can boost long-term growth, particularly where market failures lead to under-investment in the private sector (IMF, 2015). 
Moreover, recent OECD empirical work suggests a large positive effect of public investment on productivity (Fournier and Johansson, 2016).

Figure 7. The slowdown in capital stock growth and the post-crisis change in government investment

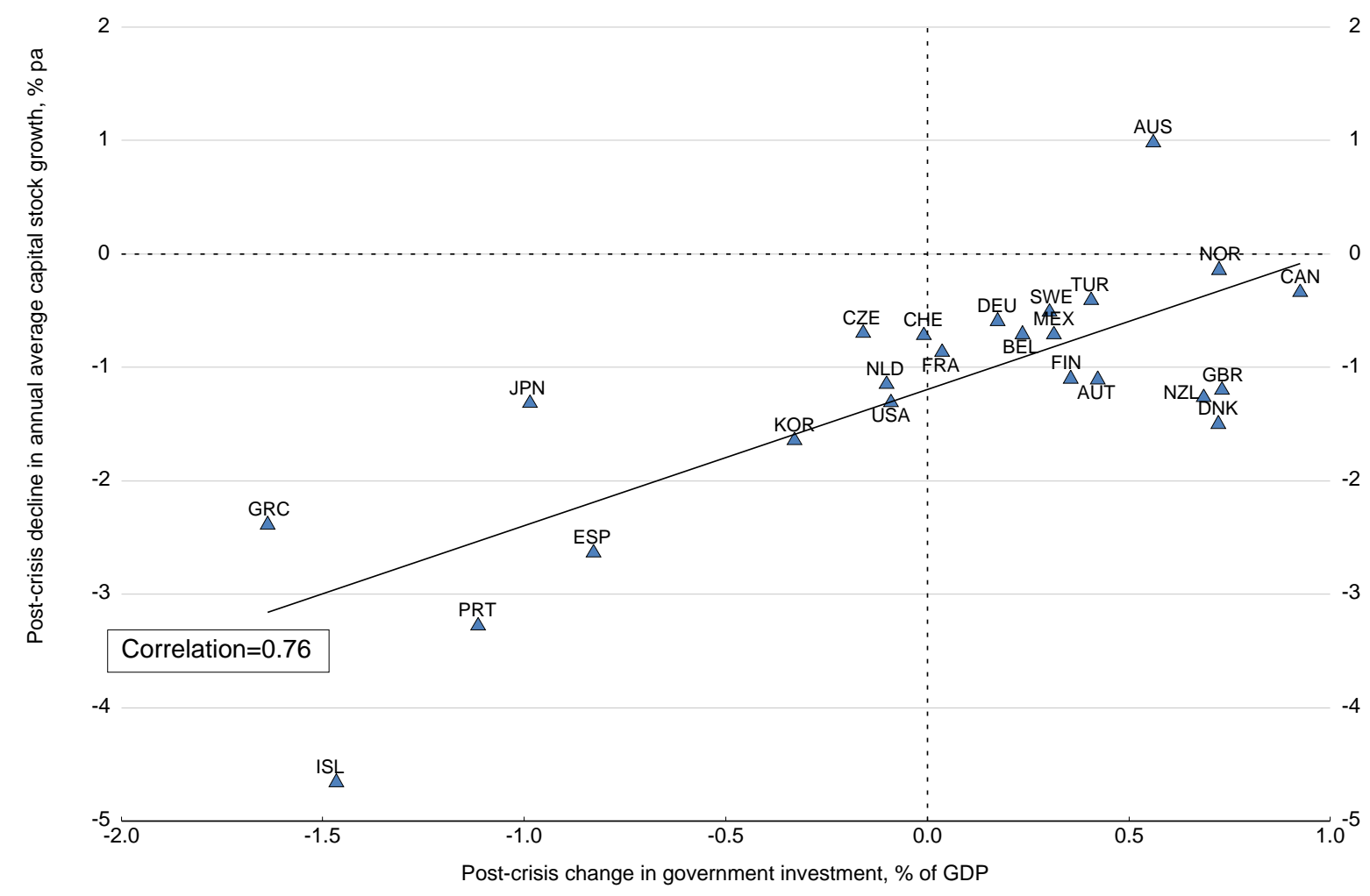

Source: OECD Economic Outlook 99 database.

\subsection{The contribution from product market regulation reforms}

20. Among the many factors contributing to weak investment and productivity growth, many can be summarised under the "fragmentation" headline: the heterogeneous policies, rules, laws and industry practices that create perverse incentives and block business efficiency and productivity growth (OECD, 2016b). More narrowly, recent empirical work in the Economics Department suggests that structural reforms which promote competition in product markets tend to boost capital intensity, albeit with long lags (OECD, 2015b; Égert, 2016; and Égert and Gal, 2016). However, while competition-enhancing product market regulation has continued to improve, the rate of improvement has declined in the post-crisis period (Figure 8). Given the bounded nature of the OECD index measuring product market regulation, rapid improvement cannot be sustained in all countries. However, in most OECD countries, a significant gap with the best performing countries remains, suggesting further scope for improvement. Thus, at a time when the use of macro policy instruments has become increasingly constrained, the waning enthusiasm for structural reform represents a missed opportunity. 
ECO/WKP(2016)28

Figure 8. Improvement in product market regulation across OECD countries

Average annual change in the OECD median indicator score for product market regulation in the network industries

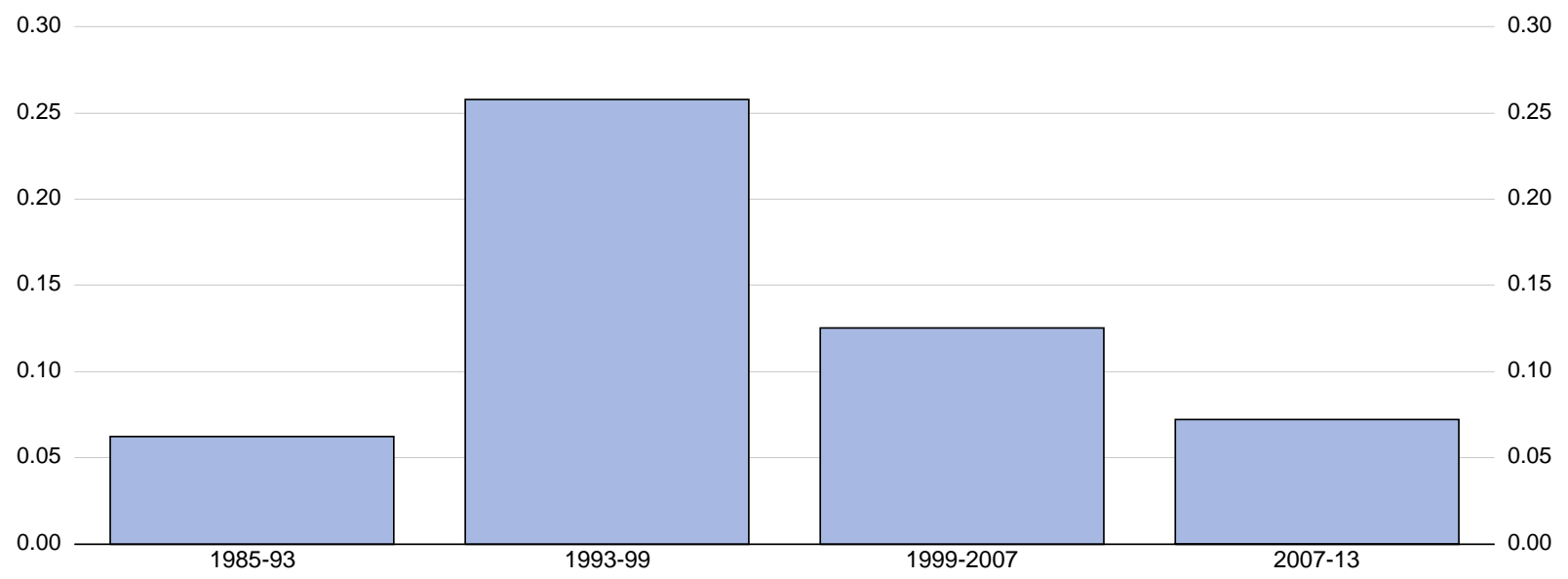

Source: OECD PMR database. 


\section{BIBLIOGRAPHY}

Bom, P. and J. Lighart (2014), "What have we learned from three decades of research on the productivity of public Capital", Journal of Economic Surveys, Vol. 28, Chapter 5.

Borio, C., E. Karroubi, C. Upper and F. Zampolli (2015), "Labour reallocation and productivity dynamics ;: financial causes, real consequences" BIS Working Papers, No. 534, Bank for International Settelements.

Égert, B. (2016), "Regulation, Institutions and Aggregate Investment: New Evidence from OECD Countries", OECD Economics Department Working Papers, forthcoming.

Égert, B. and P. Gal (2016), "The Quantification of Structural Reforms: A New Framework”, OECD Economic Studies, forthcoming.

Fournier, J-M. and A. Johansson (2016), "The effect of the size and the mix public spending on growth and inequality", OECD Economics Department Working Papers, forthcoming.

Hall, R. (2016), “Macroecnomics of Persistent Slumps”, NBER Working Paper, No. 22230, May.

IMF (2015), “Making Public Investment more Efficient”, IMF Staff Report, IMF.

Johansson, Å., et al. (2013), "Long-Term Growth Scenarios", OECD Economics Department Working Papers, No. 1000.

OECD (2013), OECD Economic Outlook, Vol. 2013/1 (May), OECD Publishing, http://dx.doi.org/10.1787/eco_outlook-v2013-1-en.

OECD (2015a), "Lifting Investment for Higher Sustainable Growth", Chapter 3, OECD Economic Outlook, Vol. 2015/1 (June), OECD Publishing, http://dx.doi.org/10.1787/eco_outlook-v2015-1-en.

OECD (2015b), OECD Economic Outlook, Vol. 2015/2 (November), OECD Publishing, http://dx.doi.org/10.1787/eco_outlook-v2015-2-en,

OECD (2015c), OECD Economic Outlook, Vol. 2015/1 (June), OECD Publishing, http://dx.doi.org/10.1787/eco_outlook-v2015-1-en.

OECD (2016a), OECD Economic Outlook, Vol. 2016/1 (June), OECD Publishing, http://dx.doi.org/10.1787/eco_outlook-v2016-1-en.

OECD (2016b), OECD Business and Finance Outlook 2016, OECD Publishing, http://dx.doi.org/10.1787/9789264257573-en.

Ollivaud, P. and D. Turner (2014), "The effect of the global financial crisis on OECD potential output", OECD Economic Studies, Volume 2014.

Turner, D. et al. (2016), "An investigation into improving the real-time reliability of OECD output gap estimates", OECD Economics Department Working Papers, No. 1294. 
ECO/WKP(2016)28

\section{APPENDIX 1. COUNTRY-SPECIFIC DECOMPOSITIONS OF POTENTIAL GROWTH}

This appendix provides a set of charts, one for each OECD country, decomposing the growth in potential output per capita using the current OECD framework for estimating potential output. This framework assumes a Cobb-Douglas production function, whereby potential output $\left(\mathrm{Y}^{*}\right)$ is expressed in terms of potential employment $\left(\mathrm{N}^{*}\right)$, the capital stock $(\mathrm{K})$ and labour-augmenting trend technical progress (E*), so that:

$$
\mathrm{y}^{*}=\alpha\left(\mathrm{n}^{*}+\mathrm{e}^{*}\right)+(1-\alpha) \mathrm{k}
$$

where lower case letters denote logs and $\alpha$ is the wage share. Total factor productivity growth (TFP) is a simple transformation of labour efficiency: $\mathrm{tfp}=\alpha \mathrm{e}^{*}$.

Potential output per head of population $(\mathrm{P})$ can be explained in terms of two components: trend productivity and a labour utilisation rate, as follows:

$$
\Delta\left(y^{*}-\mathrm{p}\right)=\Delta\left(\mathrm{y}^{*}-\mathrm{n} *\right)+\Delta\left(\mathrm{n}^{*}-\mathrm{p}\right) .
$$

The trend productivity component can be split into two components, which can be derived from combining [A.1] and [A.2], to give a contribution from labour efficiency (or equivalently a contribution from total factor productivity) and a contribution from changes in capital per worker, represented as:

$$
\Delta\left(\mathrm{y}^{*}-\mathrm{n}^{*}\right)=\alpha \Delta \mathrm{e}^{*}+(1-\alpha) \Delta\left(\mathrm{k}-\mathrm{n}^{*}\right) .
$$

The potential employment component, the second term in (2), can also be split into two parts:

$$
\Delta\left(n^{*}-\mathrm{p}\right)=\Delta\left(\mathrm{n}^{*}-\mathrm{pwa}\right)+\Delta(\mathrm{pwa}-\mathrm{p})
$$

where the first term is potential employment expressed as share of the population of working age (PWA, here taken to be the population aged 15 to 74) and the second term captures a demographic effect, hereafter referred to as the working age population share, which is the share of the total population which is of working age.

An expression for potential growth per capita, which is the basis for the decomposition in the following charts, can then be derived by combining expressions [A.2], [A.3] and [A.4]:

$$
\Delta\left(\mathrm{y}^{*}-\mathrm{p}\right)=\alpha \Delta \mathrm{e}^{*}+(1-\alpha) \Delta\left(\mathrm{k}-\mathrm{n}^{*}\right)+\Delta\left(\mathrm{n}^{*}-\mathrm{pwa}\right)+\Delta(\mathrm{pwa}-\mathrm{p}) .
$$


Figure A1.1. Decomposition of growth of potential output per capita
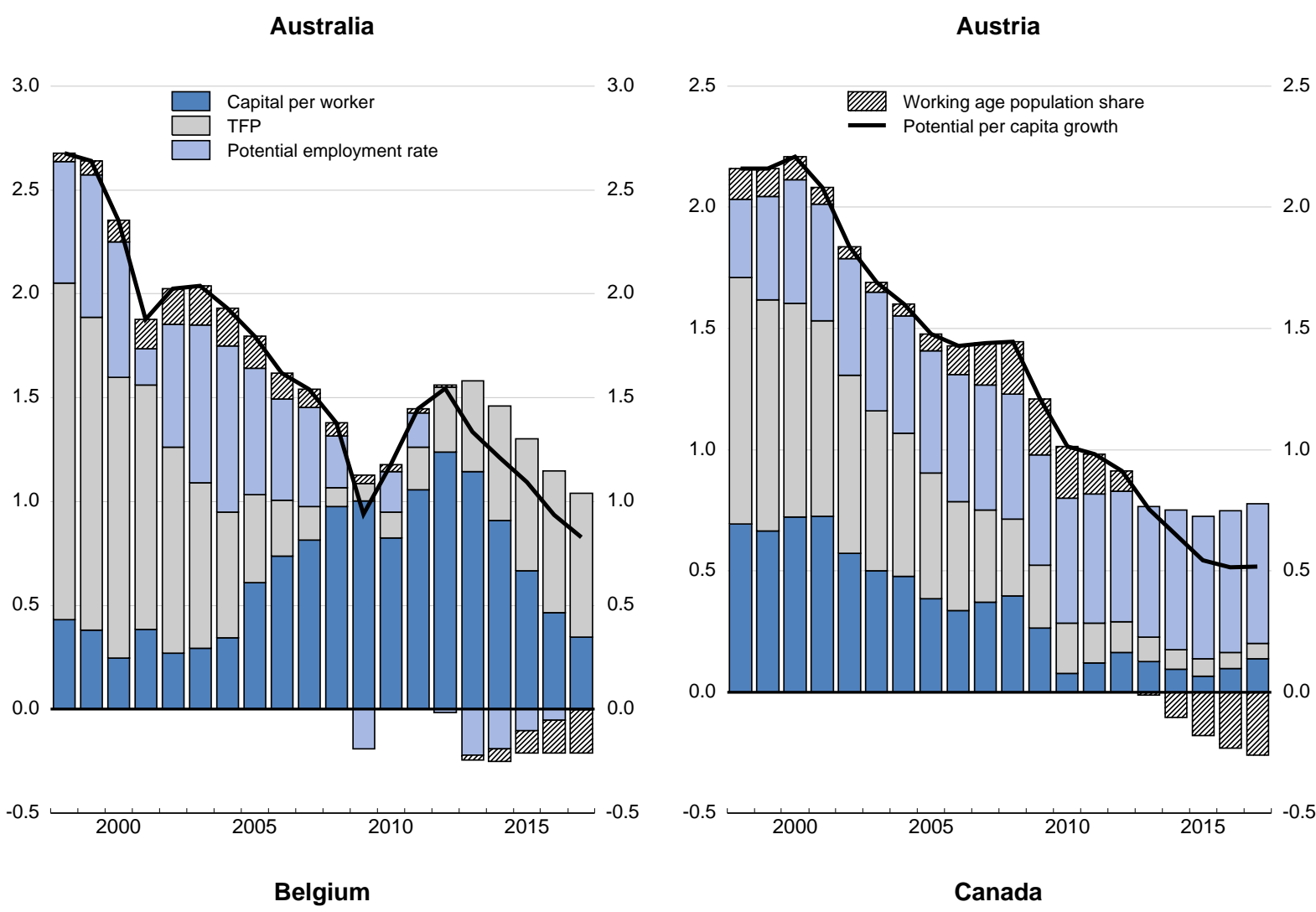

2.5

2.5

2.5
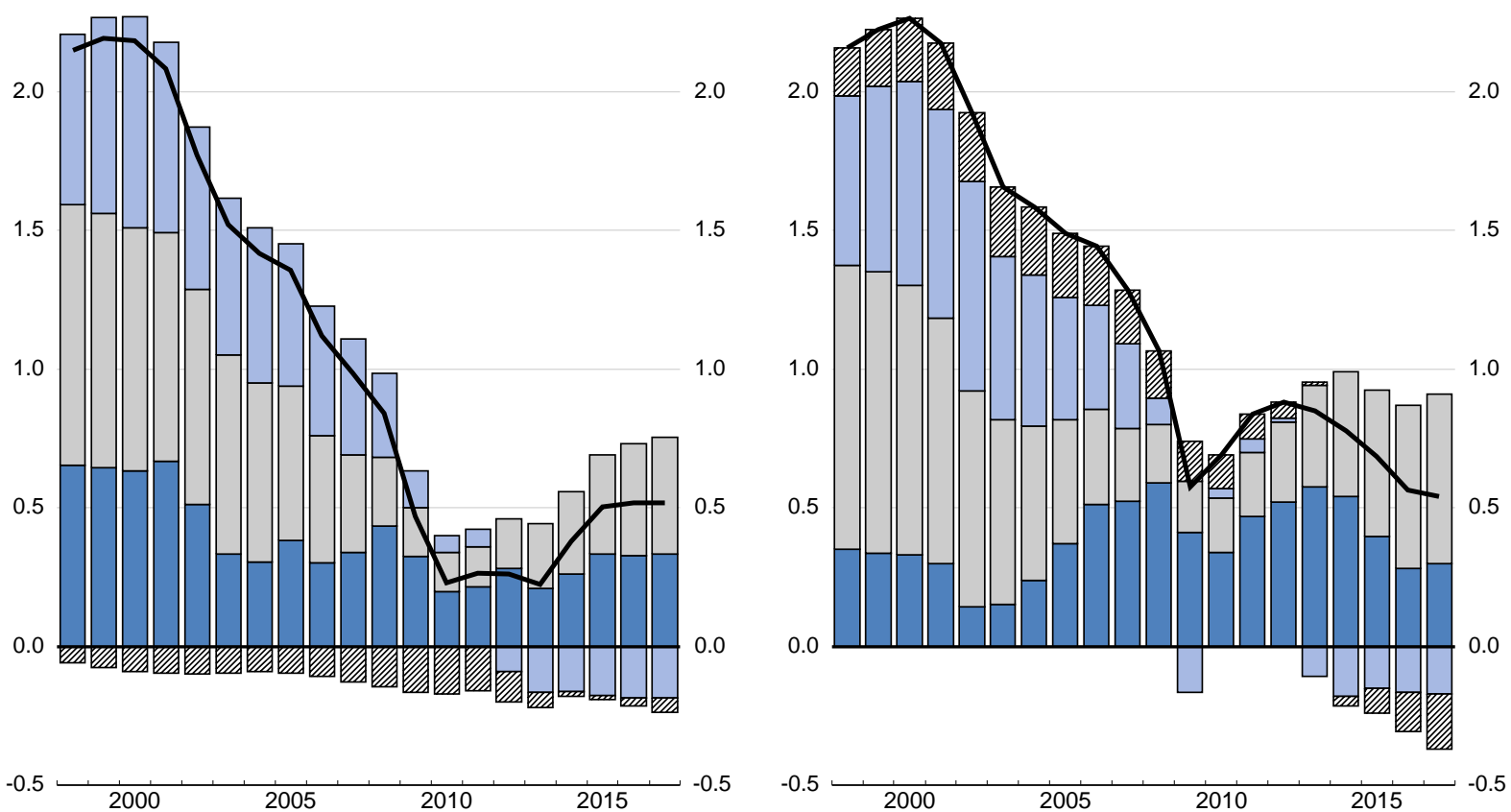

Source: OECD Economic Outlook 99 database. 
Figure A1.1. Decomposition of growth of potential output per capita (contd.)
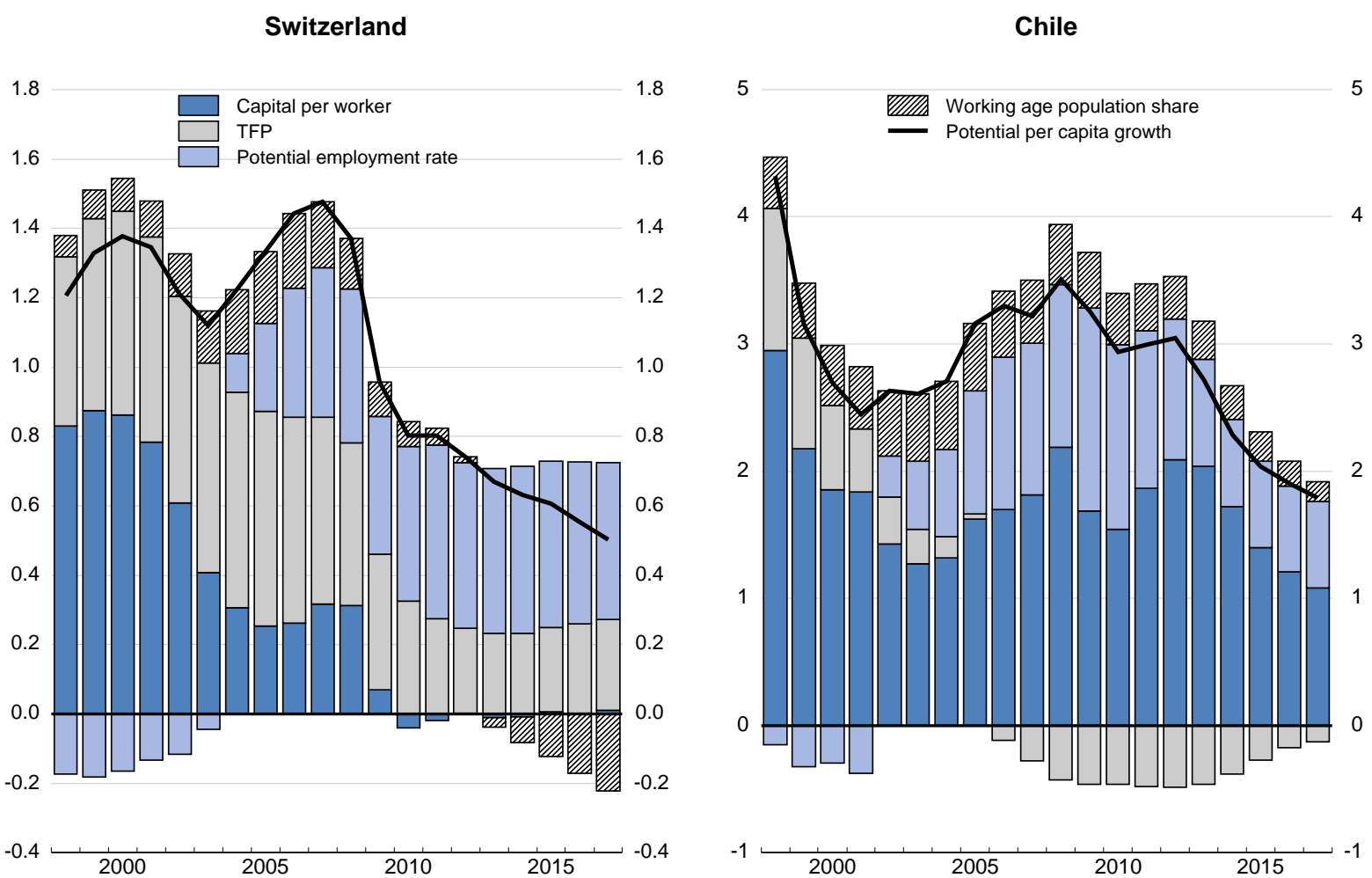

Czech Republic

Germany

5

5

2.0
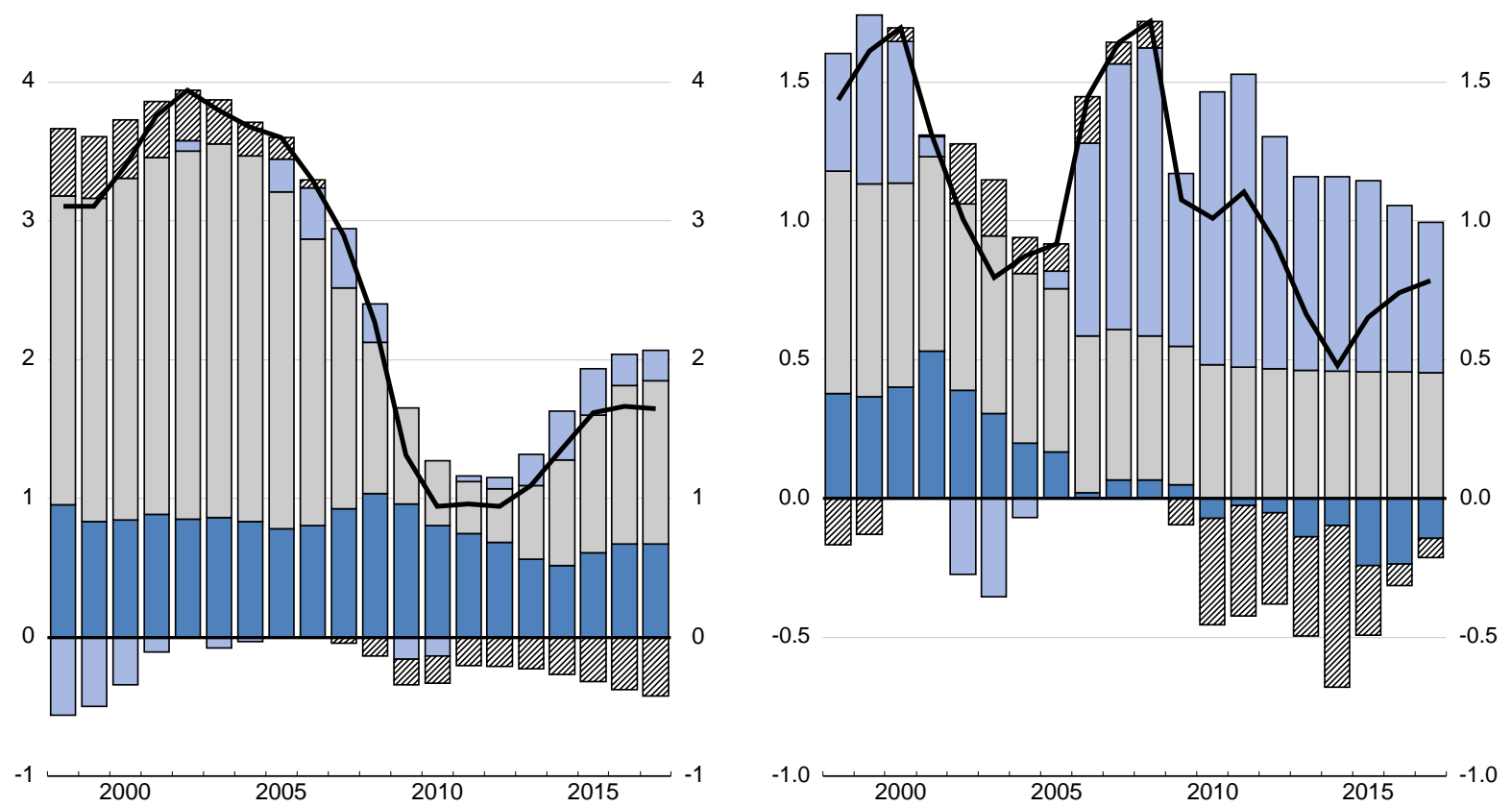

Source: OECD Economic Outlook 99 database. 
Figure A1.1. Decomposition of growth of potential output per capita (contd.)
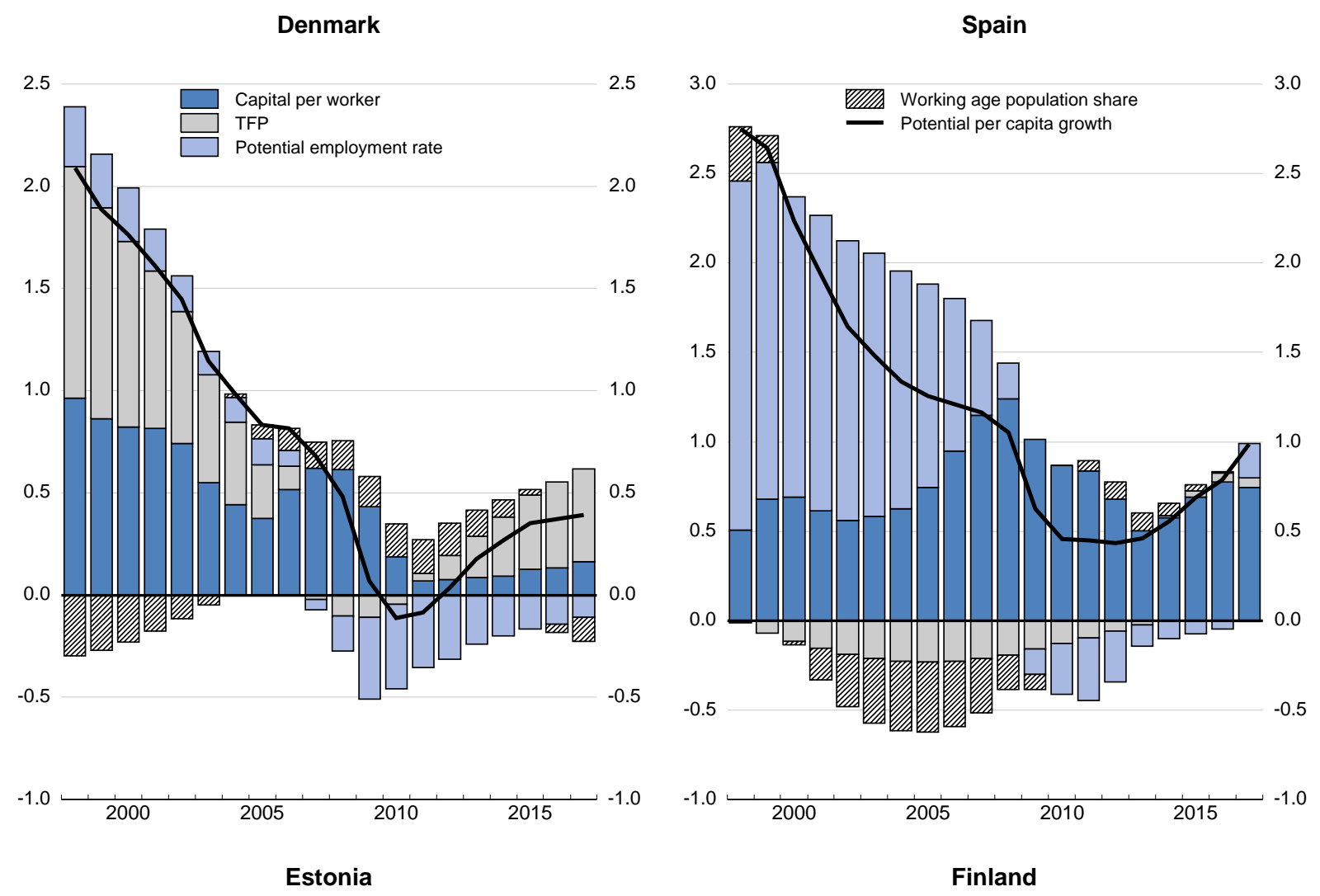

7

7
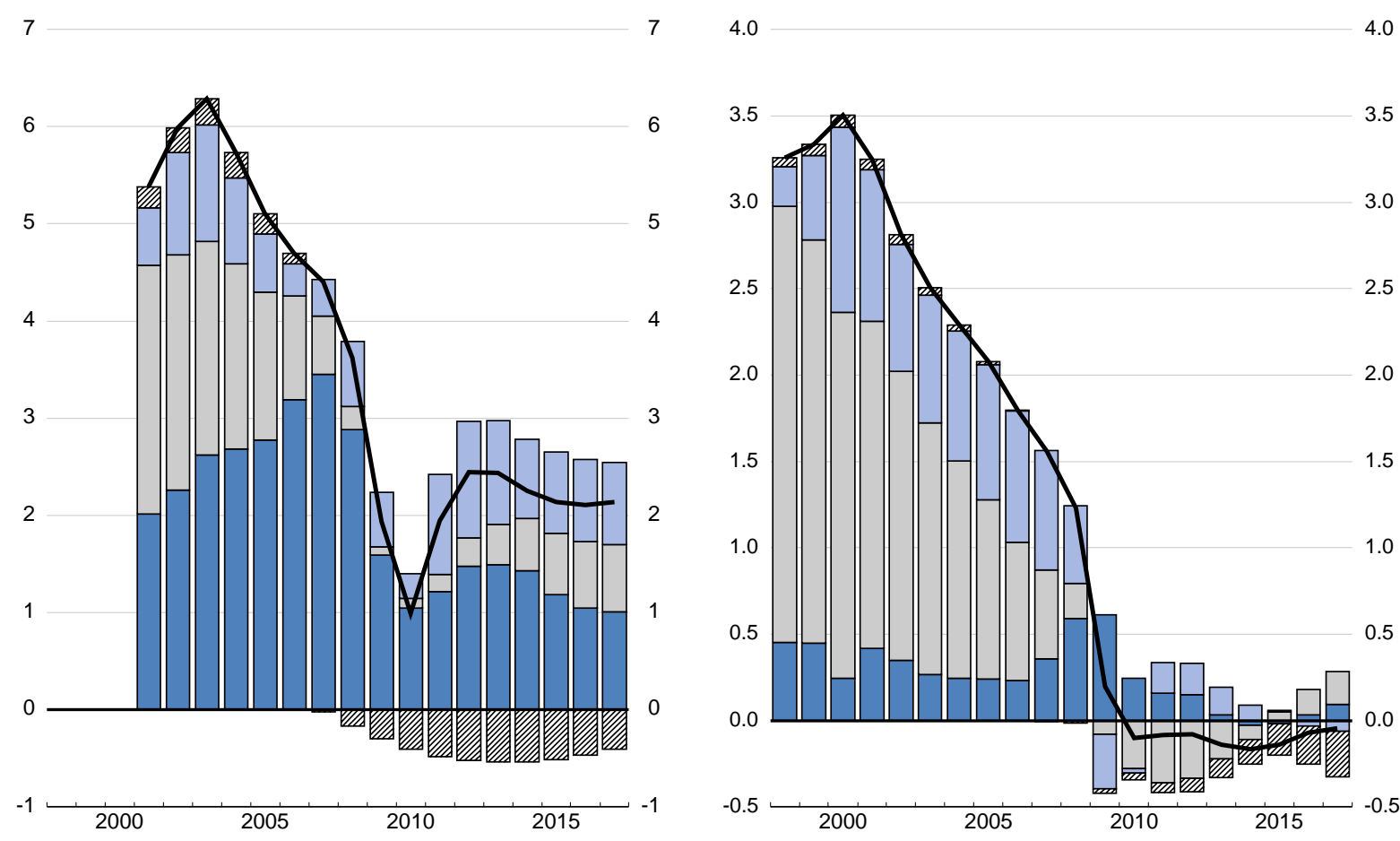

Source: OECD Economic Outlook 99 database. 
Figure A1.1. Decomposition of growth of potential output per capita (contd.)

\section{France}
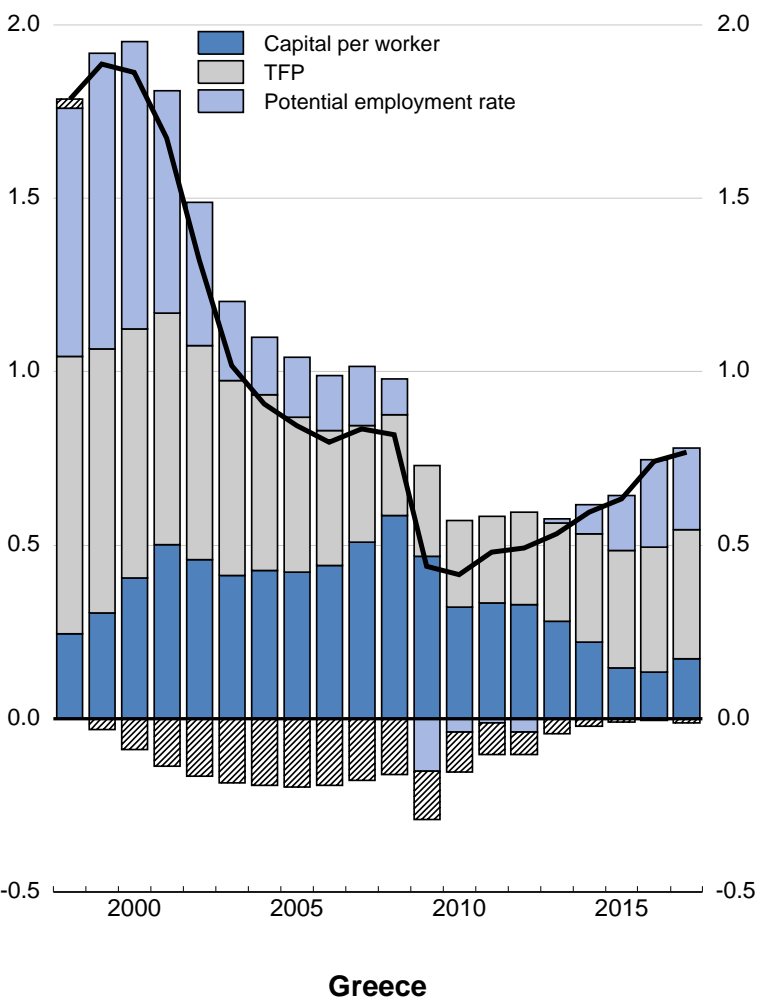

4
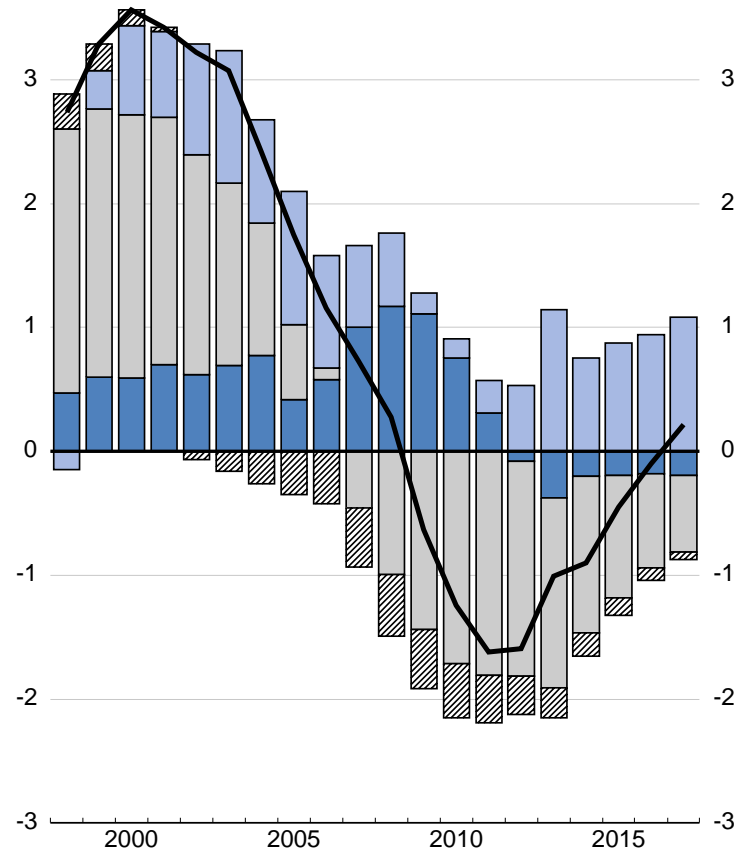

United Kingdom
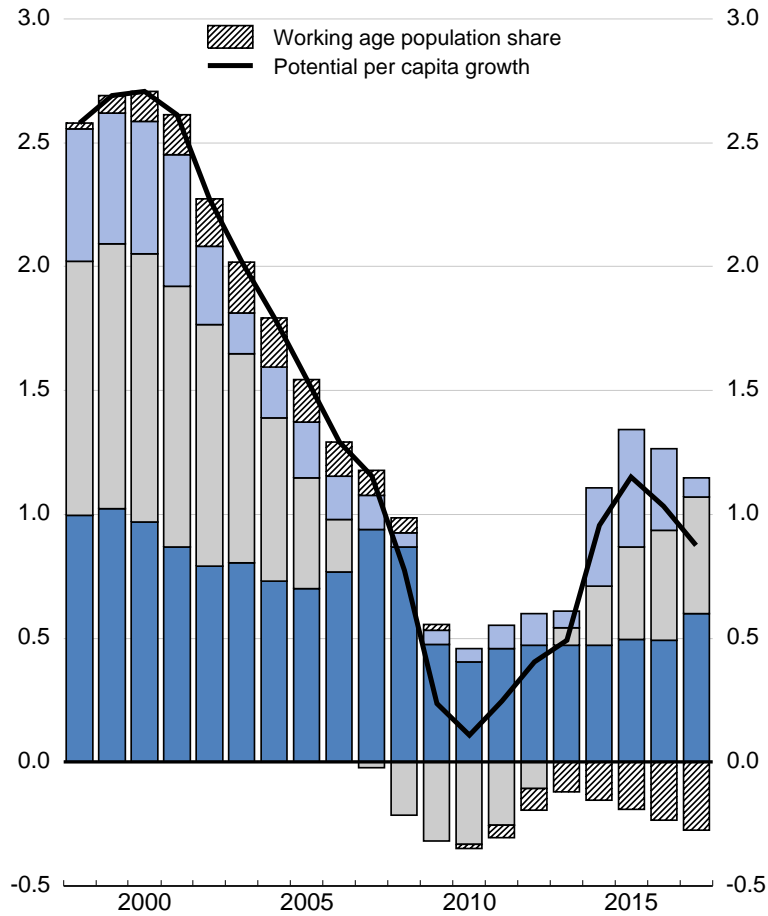

Hungary
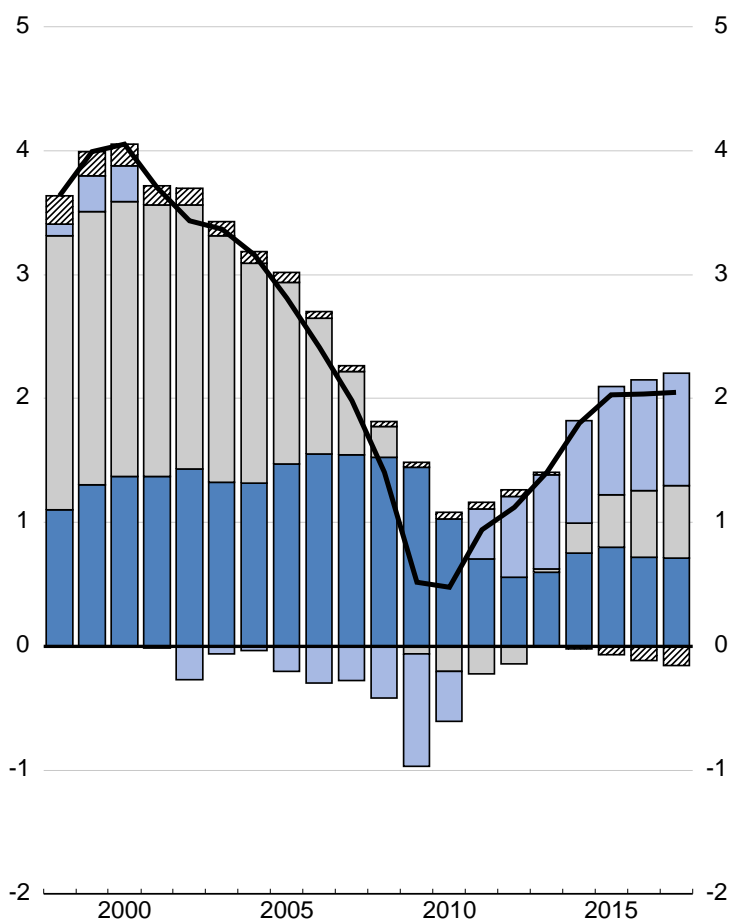

Source: OECD Economic Outlook 99 database. 
Figure A1.1. Decomposition of growth of potential output per capita (contd.)
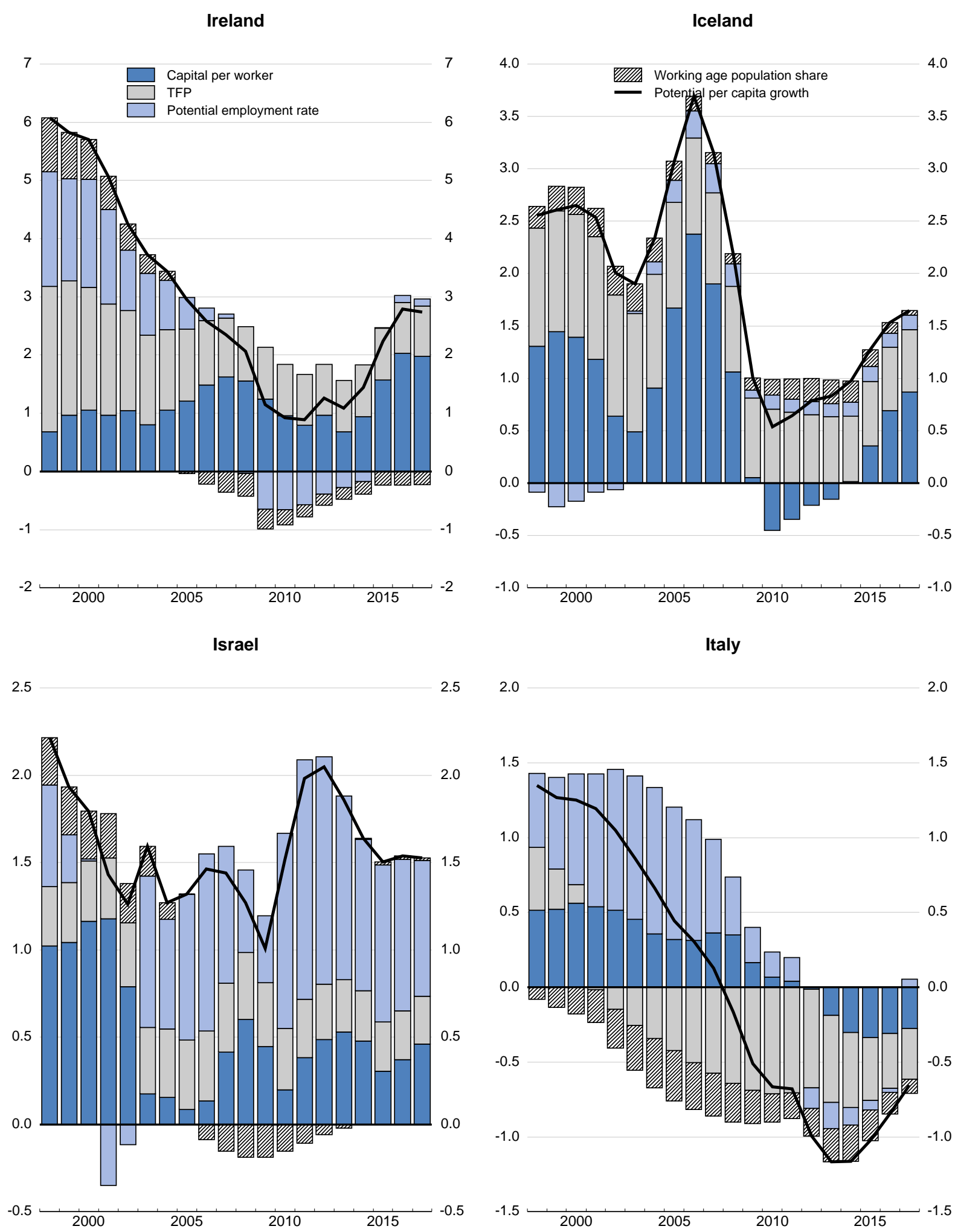

Source: OECD Economic Outlook 99 database. 
Figure A1.1. Decomposition of growth of potential output per capita (contd.)
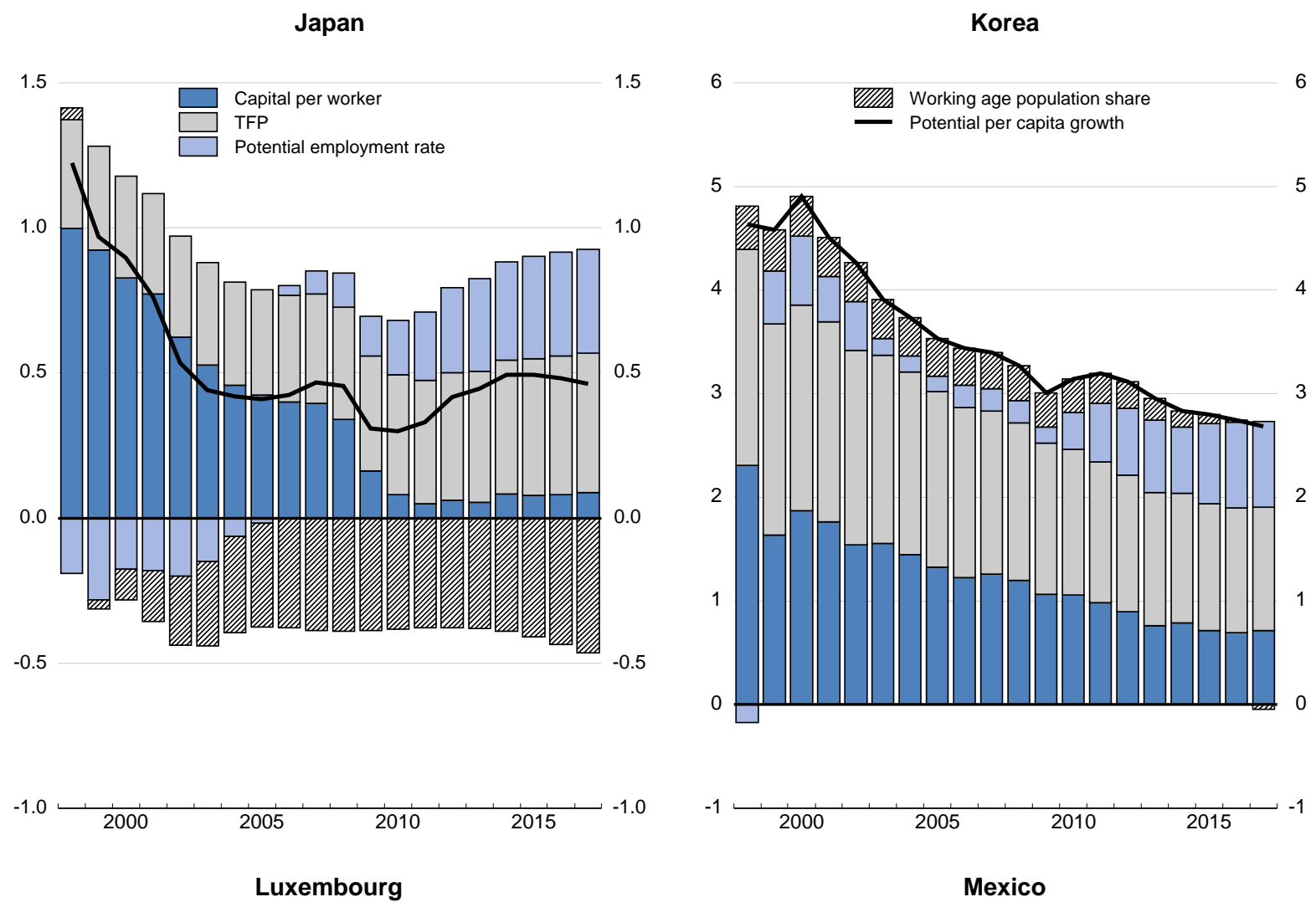

4.0 4.0 2.5 2.5
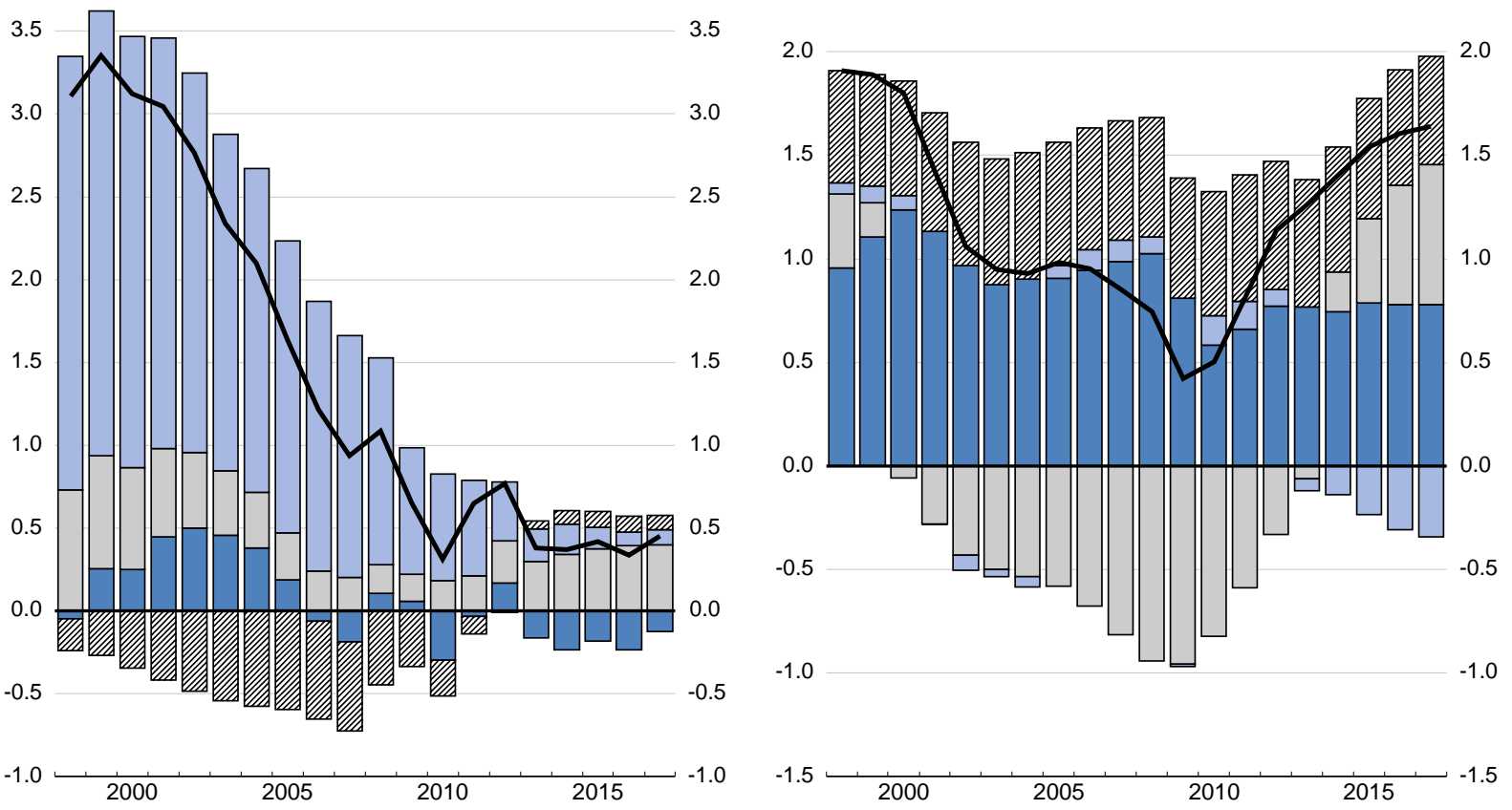

Source: OECD Economic Outlook 99 database. 
Figure A1.1. Decomposition of growth of potential output per capita (contd.)
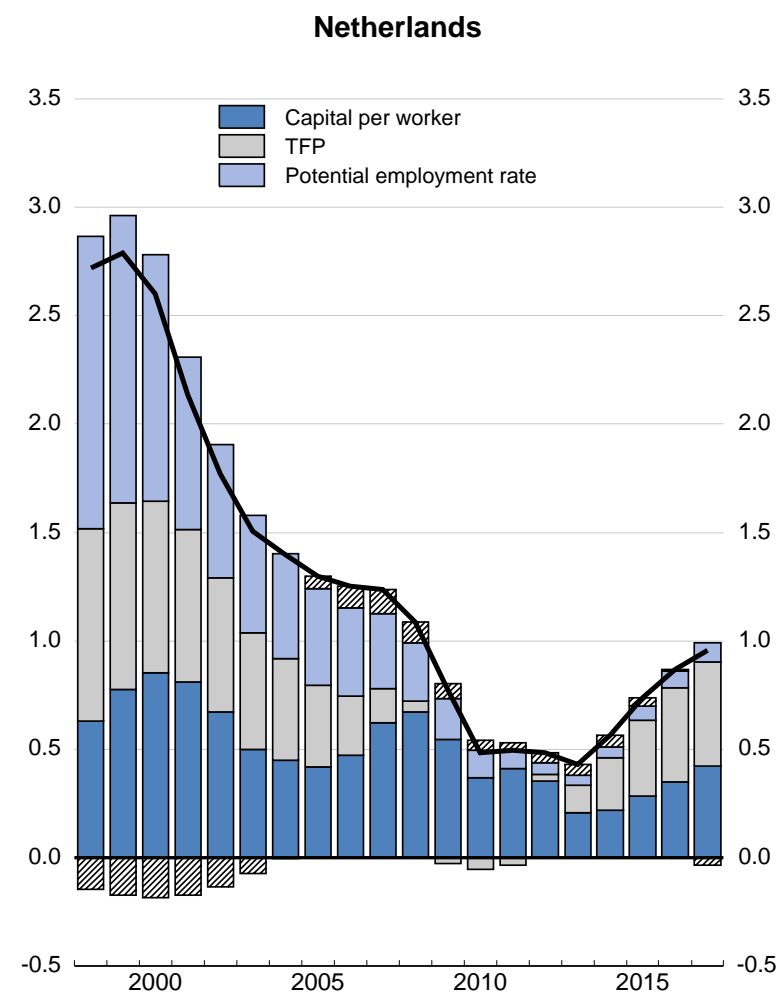

New Zealand
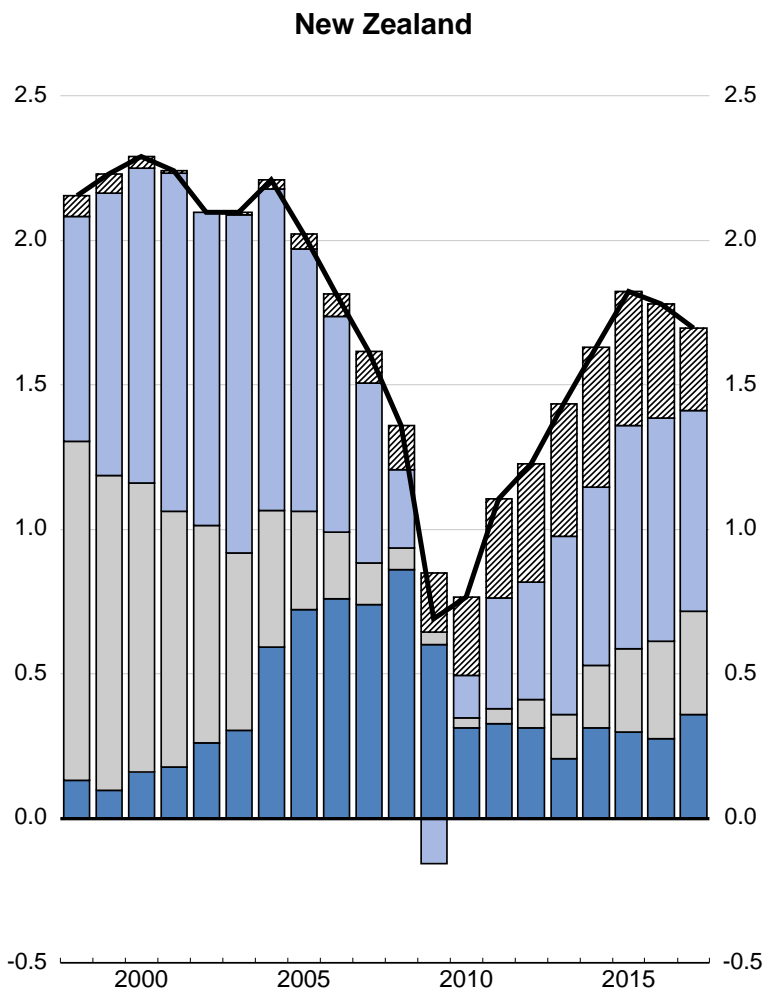
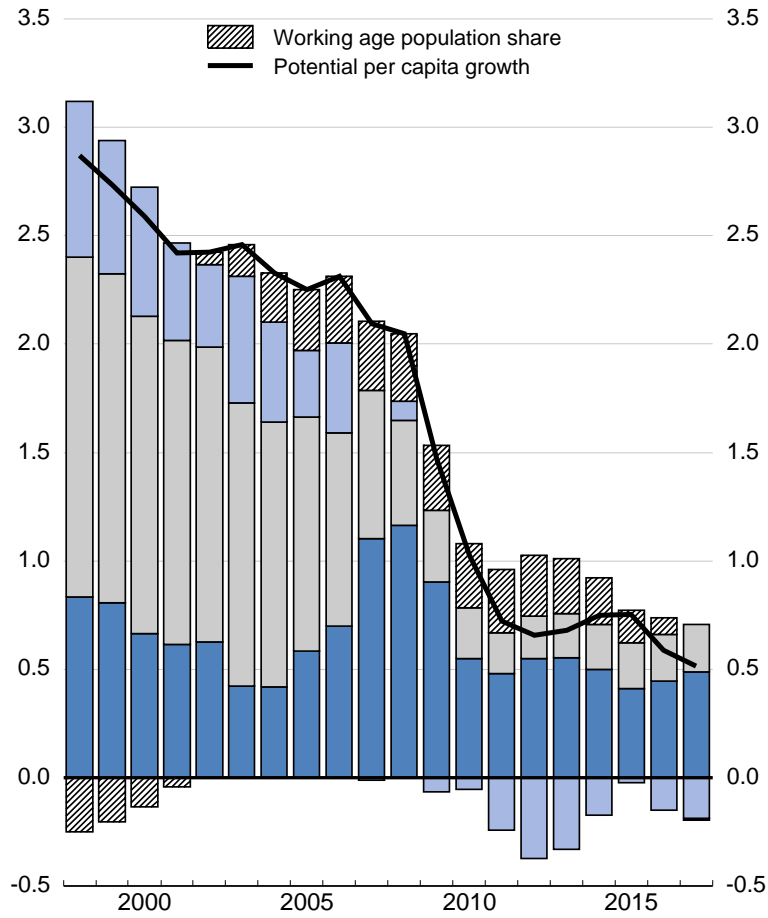

Norway

Poland
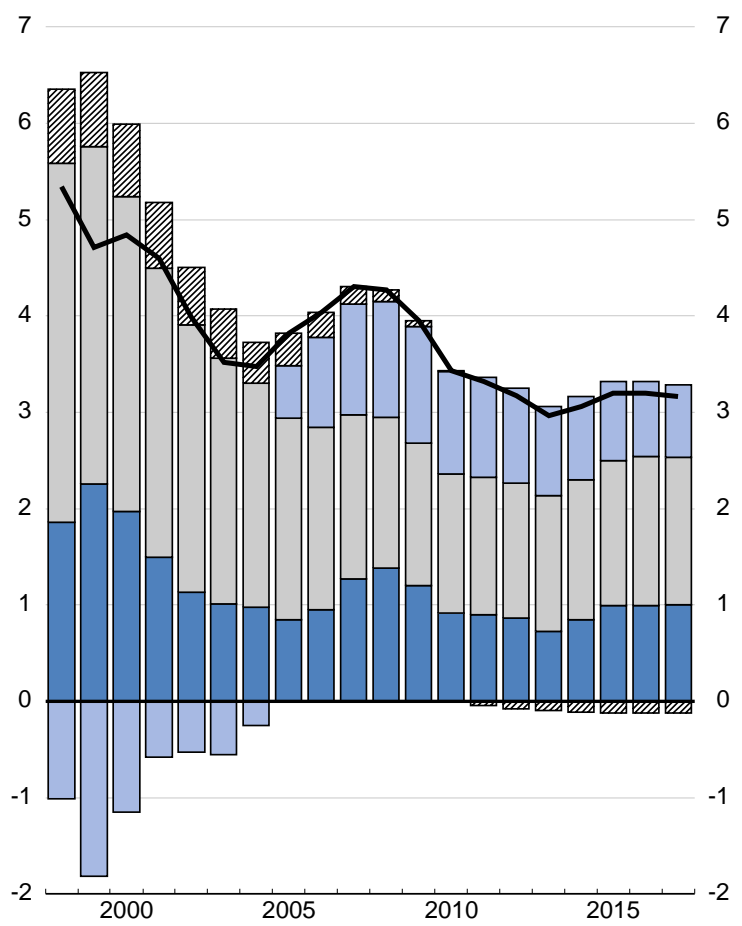

Source: OECD Economic Outlook 99 database. 
Figure A1.1. Decomposition of growth of potential output per capita (contd.)

Portugal

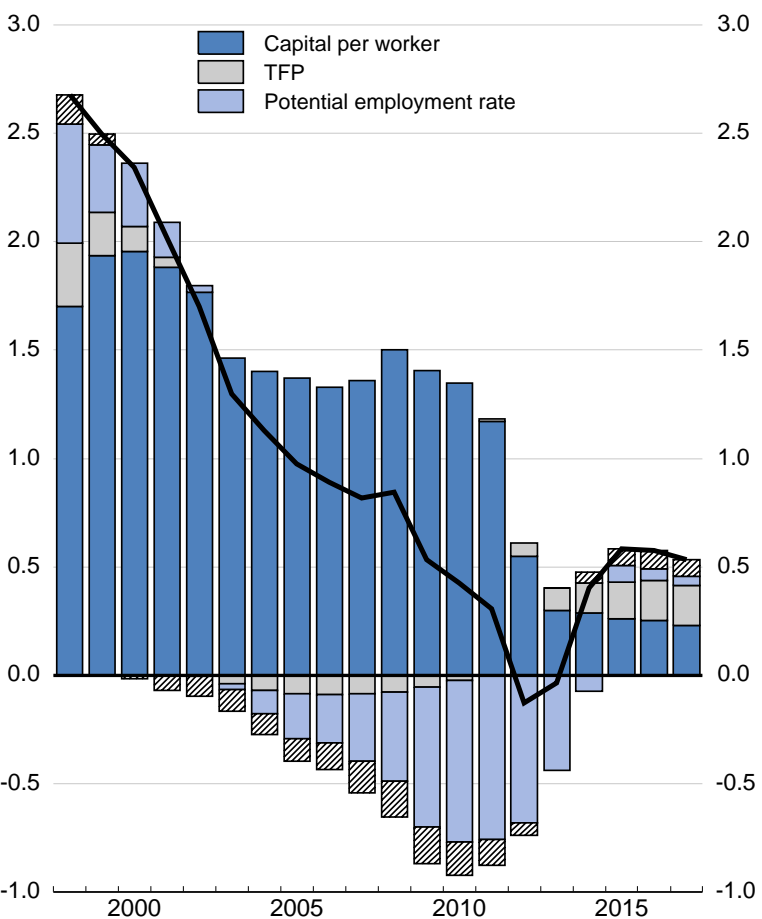

Slovenia

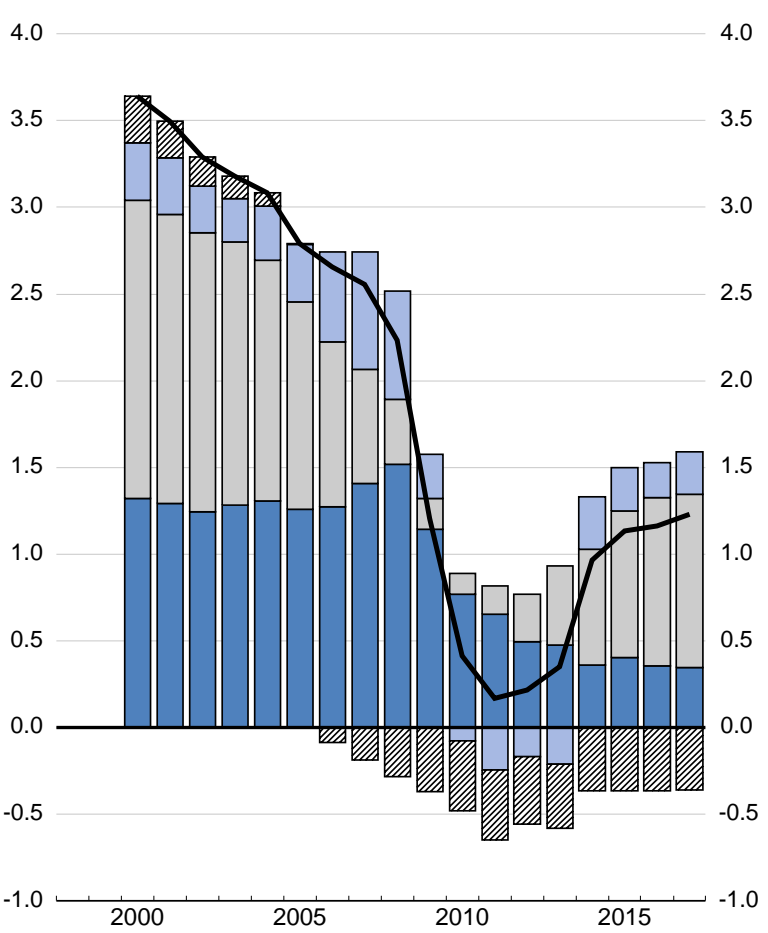

Slovak Republic

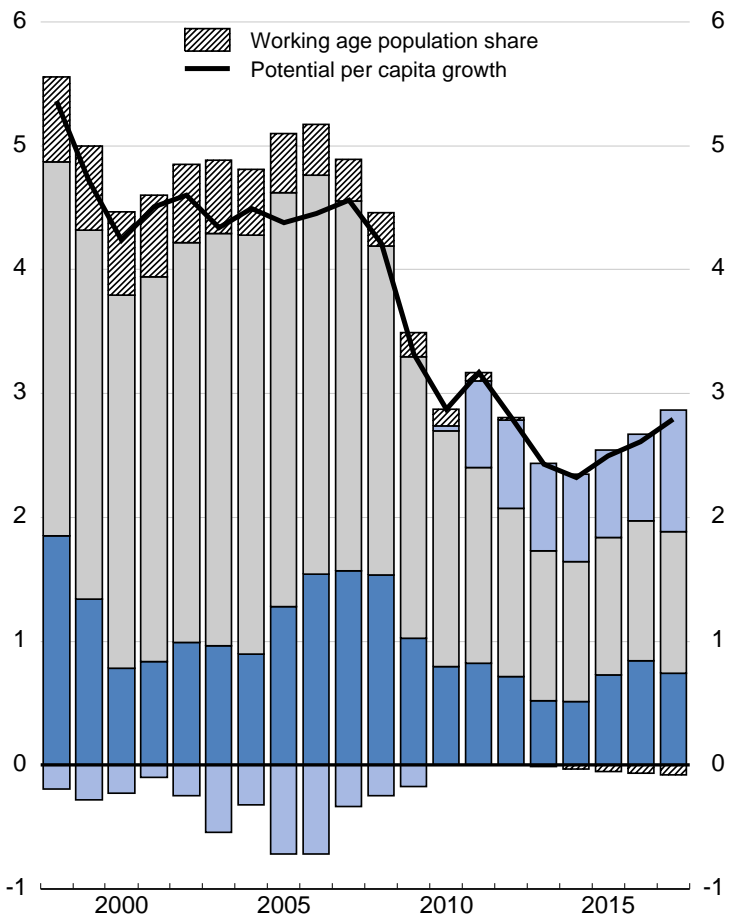

Sweden
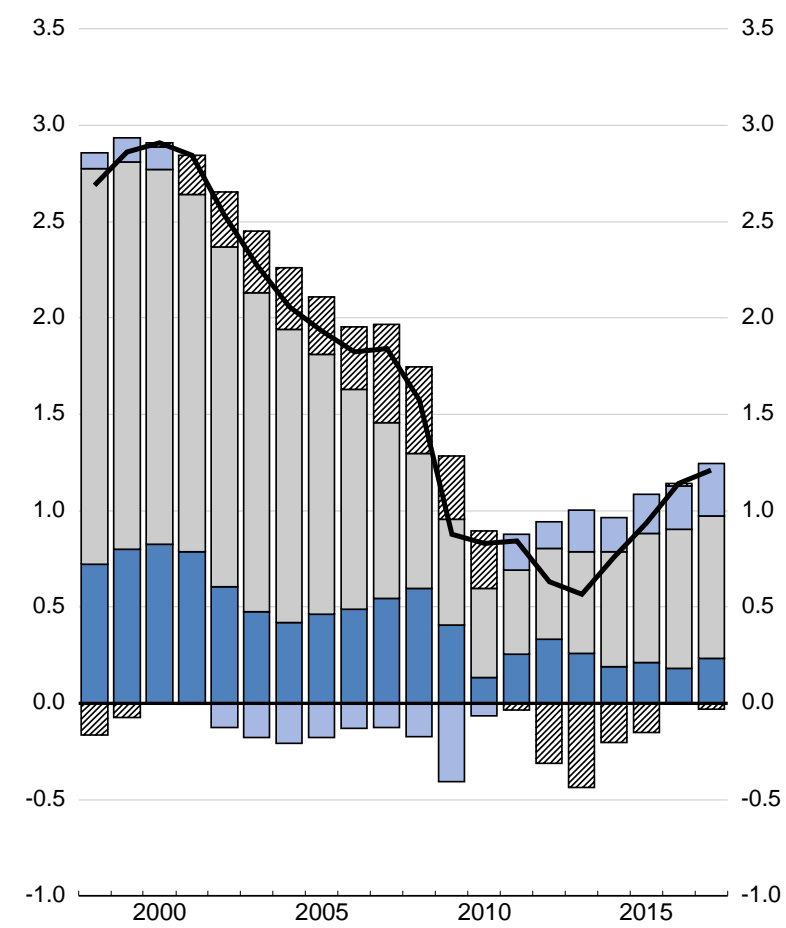

Source: OECD Economic Outlook 99 database. 
Figure A1.1. Decomposition of growth of potential output per capita (contd.)

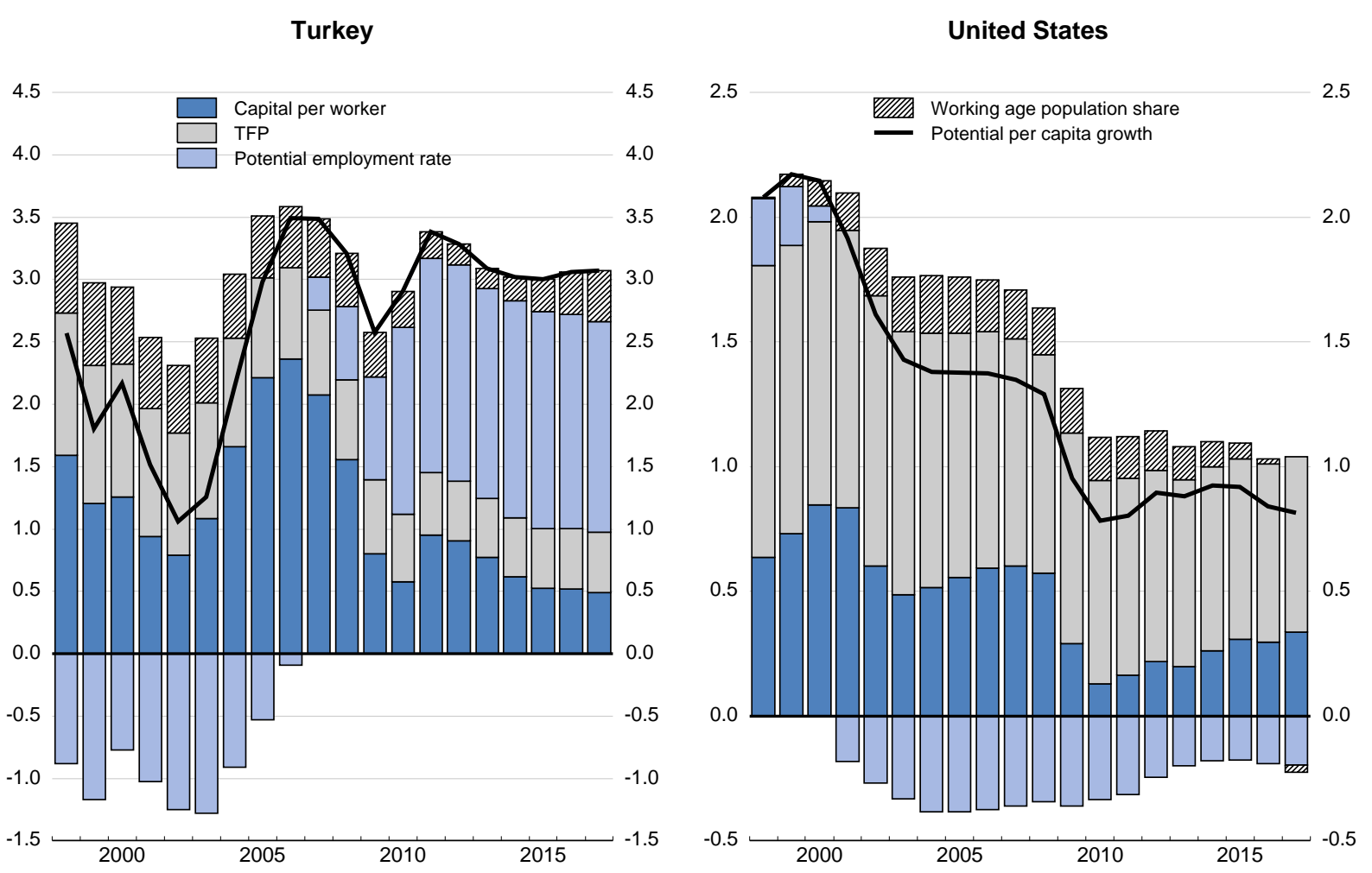

Source: OECD Economic Outlook 99 database. 